$12-1-2007$

\title{
Swept Under the Rug? A Historiography of Gender and Black Colleges
}

MaryBeth Gasman

University of Pennsylvania, mgasman@gse.upenn.edu

Follow this and additional works at: https://repository.upenn.edu/gse_pubs

Part of the Cultural History Commons, and the Women's History Commons

\section{Recommended Citation}

Gasman, M. (2007). Swept Under the Rug? A Historiography of Gender and Black Colleges. Retrieved from https://repository.upenn.edu/gse_pubs/190

Postprint version. The final, definitive version of this article has been published in the American Educational Research Journal, Volume 44, Issue 4, December 2007, pages 760-805. @ Publications, Inc. or Society/Proprietor, $2008>$ by SAGE Publications, Inc. at http://aer.sagepub.com/cgi/content/abstract/44/4/760

This paper is posted at ScholarlyCommons. https://repository.upenn.edu/gse_pubs/190

For more information, please contact repository@pobox.upenn.edu. 


\title{
Swept Under the Rug? A Historiography of Gender and Black Colleges
}

\author{
Abstract \\ This historiography of gender and black colleges uncovers the omission of women and gender relations. \\ It uses an integrative framework, conceptualized by Evelyn Nakano Glenn, that considers race and gender \\ as mutually interconnected, revealing different results than might be seen by considering these issues \\ independently. The article is significant for historians and nonhistorians alike and has implications for \\ educational policy and practice in the current day. \\ Keywords \\ black colleges, African Americans, black women, gender, history \\ Disciplines \\ Cultural History | Women's History \\ Comments \\ Postprint version. The final, definitive version of this article has been published in the American \\ Educational Research Journal, Volume 44, Issue 4, December 2007, pages 760-805. ( Publications, Inc. \\ or Society/Proprietor, 2008> by SAGE Publications, Inc. at http://aer.sagepub.com/cgi/content/abstract/ \\ $44 / 4 / 760$
}




\title{
Swept Under the Rug? A Historiography of Gender and Black Colleges
}

\author{
Marybeth Gasman \\ University of Pennsylvania
}

This historiography of gender and black colleges uncovers the omission of women and gender relations. It uses an integrative framework, conceptualized by Evelyn Nakano Glenn, that considers race and gender as mutually interconnected, revealing different results than might be seen by considering these issues independently. The article is significant for historians and nonhistorians alike and has implications for educational policy and practice in the current day.

KeYwORDs: black colleges, African Americans, black women, gender, history

$T^{1}$ There is perhaps no intracommunity topic about which there has been more contentious debate than the issue of gender relations in black America. We also believe that the proverbial "battle between the sexes" has caused deep ruptures in the cohesiveness of African American communities that have not gone unnoticed. ${ }^{1}$

According to Johnnetta B. Cole and Beverly Guy-Sheftal, within African American communities, issues of gender are rarely discussed except among a "small group of feminists and other gender-progressives." ${ }^{2}$ These conversations, although at the heart of many problems within the larger black community, are "swept under the rug" by both men and women, usually in order to bring the fight for racial equality to the foreground. Cole and Guy-Sheftal argue that speaking about gender relations within the African American community can result in being labeled a "race traitor" or a "male basher." Similarly, Patricia Hill Collins, in her provocative book Black Feminist Thought, maintains that the goal of racial solidarity mandates that black women remain silent about certain aspects of black male-female relationships. ${ }^{4}$ Evelyn Nakano

Marybeth Gasman is an Assistant Professor in the Division of Policy, Management, and Evaluation, Graduate School of Education, University of Pennsylvania, 3700 Walnut Street, Room 423A, Philadelphia, PA 19104; e-mail: MGASMAN@gse.upenn.edu. Dr. Gasman uses historical methods to explore issues related to African American higher education. Her particular areas of interest include black colleges and universities, African American leadership, fund-raising, and African American philanthropy. 


\section{Gasman}

Glenn notes that 'in studies of 'race,' men of color stood as the universal racial subject, whereas in studies of 'gender,' [w] hite women were positioned as the universal female subject. Women of color were left out of both narratives, rendered invisible both as racial and as gendered subjects." Gender and race have historically operated in "separate fields of scholarly inquiry."

Beginning in the 1980s, black women started to address their omission from historical literature, lodging criticism against African American male historians in general for their omission of gender issues and women overall. Moreover, when black male historians have covered black women in their research, some scholars have characterized this coverage as "troubling," noting that often when black male historians transform "the dehumanizing images of black womanhood," they "cast black women as specific 'types' and describe black female leaders and activists in non-threatening terms." Recent scholarship on the history of black colleges continues to exclude substantive discussion of black women. ${ }^{8}$ Here, the focus is almost entirely on malesincluding white male philanthropists, presidents, and missionaries as well as black male presidents, faculty, and students. ${ }^{9}$ Discussion of black women or the relationships between men and black women within the black college context is limited. This omission is especially troubling in light of the fact that throughout the history of black colleges, female students have been in the majority (with the exception of 1947, a year that marked the apex of enrollment by returning black male veterans). ${ }^{10}$ Of course, black women have not constituted the majority of black college leadership positions; these ranks have been dominated by white and black men.

In the words of Florence Bonner, the black college "foundation of religious-based formal education and the popular argument that these institutions provide a constant social defense against racism have created a powerful torque of resistance to discussions focusing on the manner in which women have been treated and educated at [black colleges]." 11 When discussions about gender do occur in the historical literature on black colleges, the emphasis is typically on the historically black women's colleges, as in Yolanda Watson and Sheila T. Gregory's new book Daring to Educate. ${ }^{12}$ Here the authors examine the leadership of Spelman College's first four white female presidents and their role in educating the black students.

Recent historiography has examined the writings on African American education and begun to notice the omission of women within education in general. For example, in 1998, historian Ronald E. Butchart observed,

Beyond occasional mention of domestic training in industrial education, the current literature says little about specific schooling for black women or about the content of the curriculum in black schools as it attempted to mold perceptions of race and sex. Black fiction is filled with images of strong, independent black women, yet nowhere in the historical literature do we learn where that characterology might have been learned outside the home; what agencies contributed to the education of black womanhood. ${ }^{13}$ 
Likewise, according to Alicia C. Collins, "Black women have been participants in higher education for more than a century, but they are almost totally absent from the research literature; rarely is the impact of racism and sexism on [b]lack women in academe examined." ${ }^{14}$ Scholars have yet to explore the black female leadership of black colleges at various levels or the relationships between black men and women at all levels in coeducational environments. And most significantly, a balanced interpretation of the history of black colleges, considering gender, has yet to be written. My article continues the historiographic analysis of the literature, including examples of action on the part of black female administrators, faculty, and students that have been omitted from the historical literature on black colleges and pointing the direction toward future areas of research.

According to Evelyn Nakano Glenn, "there are important points of congruence" between the concepts of race and gender. ${ }^{15}$ Moreover, these convergences aim toward "an integrative framework in which race and gender are defined as mutually constituted systems of relationships . . . organized around perceived differences." 16 Because black college and university environments bring together both race and gender differences, an integrative framework is most appropriate for examining the history of these institutions. ${ }^{17}$ However, as I will show, most historians writing on black colleges have not seen the combined effect of these two types of differences. While it is possible to look at race and gender in isolation, to do so obscures the complexities of the black college context. In this article, I traverse the existing literature, noting a range of stances on gender difference. Within the race-specific context of black colleges, most authors ignore gender altogether-in effect, sweeping the very existence of black women under a rug. Some authors see gender but not its relationship to race, and a few recognize the dual impact of race and gender.

In historiography, the researcher examines how the history of a topic has been written, including the historians' ideologies and arguments, the scope and foci of their work, the treatment of sources (or lack thereof), and the historical context of the work being reviewed. For the purposes of this historiography, I have divided the literature into three sections based on the dominant themes that emerged as I read these texts. ${ }^{18}$ The first is titled "Philanthropic Outside Control" and includes historical literature on black colleges that pertains to the relationships between white male industrial philanthropists and black college presidents. The majority of the literature on the history of black colleges falls into this section, as it has concentrated on philanthropy and issues of control. The second section, "Internal Campus Relations," focuses on the historical literature pertaining to activities and relationships on black college campuses. Often, this literature is jointly rooted in the sociological tradition. The third section, titled "Black Women's Higher Education," includes historical literature on black women's experiences in higher education. Because most of this literature was written prior to a time when black women represented a critical mass in historically white institutions, 


\section{Gasman}

it focuses on black colleges. However, this literature is not typically considered alongside that of the history of black colleges.

It should be noted that the field of African American women's history is quite young-arguably coming into its own about forty years ago. Some might argue that given the newness of the field, archival materials related to black women or gender relations on black college campuses have been and continue to be difficult to find. Yet over the past forty years, more diaries, letters, autobiographies, and oral histories have become available to researchers. Often, when I have come across these primary sources related to the history of black colleges, I notice that I am the first person in fifteen or twenty years to examine them. Thus, it is not necessarily that the materials are difficult to find but that few people are asking questions that lead to them. As more historians examine topics pertaining to black women and gender relations at black colleges, more primary sources will be uncovered.

\section{Coming Clean on My Own Omissions}

Before beginning a critique of others' work, I reviewed my own research. For the past ten years, my scholarly work has focused on black colleges, their funding, their leadership, and their role in the nation as a whole. Following the lead of other historians of black education, I approached my work without much thought to the issue of gender or the role of black women. My first book, a biography of Fisk University president Charles S. Johnson, avoided the subject of gender, focusing on Johnson's relationships with white male philanthropists and black male intellectuals. ${ }^{19}$ More recently, I completed a book-length history of the United Negro College Fund. In this work, I spent considerable time looking at the roles of black and white men and white women; however, I included only a few examples of the roles that black women played in this important organization. ${ }^{20}$ Only when a colleague who was writing a book on the subject of gender and education asked me to contribute a chapter on gender issues within the black college setting did I begin to appreciate the extent of black women's contributions.

\section{The Historical Literature on Black Colleges}

The first black colleges were founded in the North prior to the Civil War: Lincoln and Cheyney universities in Pennsylvania and Wilberforce in Ohio; the remaining were founded after 1865. In the aftermath of the war, the daunting task of providing education to over four million formerly enslaved black men and women was shouldered by both the federal government (through the Freedman's Bureau) and by many Northern church missionaries. ${ }^{21}$ As early as 1865, the Freedmen's Bureau began establishing black colleges, drawing many of its white staff and teachers from the ranks of the military. During this period, most black colleges were colleges in name only; like many white colleges in their infancy, these institutions generally provided primary and secondary education. From their beginnings, most of these institutions, 
unlike their historically white counterparts, provided coeducational training, as both black men and women were expected to work outside the home. ${ }^{22}$ Black women, like black men, were seen by the white missionaries and whites in general as potential workers in need of manual training. ${ }^{23}$ And black women, in particular, were educated with the underlying goal of uplifting their own race. ${ }^{24}$ black men were often viewed as only the workers of the black race rather than the leaders. ${ }^{25}$ Although racial uplift for black women was a goal of the white missionaries, the black community also advocated for it, believing that women were assets to its future. ${ }^{26}$

\section{Philanthropic Outside Control}

Several historians have explored the founding of black colleges, with particular attention to the role played by white male industrial philanthropists in that effort. ${ }^{27}$ Although this coverage provides an understanding of the relationships between white men and black men-and the complicating factor of wealth in these relationships-the role of women, both black and white, is largely absent. One of the first histories of black education came in 1919 with the publication of Carter G. Woodson's The Education of the Negro Prior to 1861: A History of the Education of the Colored People of the United States from the Beginning of Slavery to the Civil War. ${ }^{28}$ By and large, the focus of Woodson's book is on the work of white and black abolitionists and churches in providing makeshift elementary education to free blacks in the North. He also highlights the actions of several black female schoolteachers who worked against insurmountable odds to educate blacks during this time. Woodson includes one chapter on higher education and spends the majority of it discussing a now moot debate about whether blacks should be educated for a life in America or a recolonized Africa. He also explores the experiences of some black men who were able to gain admittance and thus, acquire higher education at institutions such as Bowdoin (1828) and Union College (1840). Of note is Woodson's discussion of the founding of Cheyney University (formerly the Institute for Colored Youth) and Lincoln University (formerly the Ashmun Institute). One gets the sense that he is referring to both black men and black women when discussing the faculty and students at these early black colleges, but all of the examples pertain to either white women or black men. Black women and their role are omitted from the discussion. ${ }^{29}$ This brings up one of the key problems with male-focused histories, namely, whether it is possible for the male experience to stand for that of the female? When reading Woodson, one wonders if black women played any role at all in the establishment and early operation of these institutions.

Although not a history in the truest sense nor a history of black colleges per se, one would be remiss in not mentioning Carter G. Woodson's The MisEducation of the Negro, written in 1933, in a historiography of black colleges. Within his entire book, he mentions black women or the interaction of men and women of either race only a few times; still, in these instances, Woodson speaks to issues of gender in much more detail than most historians writing 


\section{Gasman}

on black education. Woodson critiques black education at multiple levels, excoriating the white male industrial philanthropists for their need to control the minds of blacks and their lack of trust in black leadership at black institutions. With regard to the topic at hand, the historian refutes the idea that the time in which the book was written is not right to bring black leadership to the fore within the black colleges. Here, he offers examples of successful black male presidents as a challenge to those who say that blacks do not have the contacts through which to raise funds. In Woodson's words,

[Don't] we remember what Booker T. Washington did for Tuskegee and observe what R. R. Moton and John Hope are doing today? As the first Negro president of Howard University Mordecai W. Johnson has raised more money for that institution among philanthropists than all of its former presidents combined. Furthermore, if, after three generations the Negro colleges have not produced men qualified to administer their affairs, such an admission is an eloquent argument that they have failed ingloriously and should be immediately closed..$^{30}$

Of course, Woodson makes a compelling point; however, he neglects to mention those female presidents and principals who had also shown immense innovation and successfully raised funds. For example, in 1902, Mary McLeod Bethune founded the Daytona Educational and Industrial Training School for Negro Girls, which would, by 1930, become a junior college and eventually a few years later, Bethune-Cookman College.

Woodson delivers a scathing critique of the racial prejudice of the white presidents of black colleges. He is one of the few historians studying this time period to note the treatment of black women, and he does so in a way that reflects both race and gender as axes of difference. ${ }^{31}$ Woodson explains that in his professional experience, he has encountered white presidents "who will not address a colored girl as Miss, and[,] to avoid the use of a title in speaking to women of the race[,] he addresses them as his kin." Giving much credit to the keen minds of black women, Woodson notes, "One of them was sharp enough to reply to him [the white president] thus when he accosted her as auntie," she replied "Oh, I am so glad that I have found my lost relatives at last. My mother often told me that I had some distinguished kin, and just to think that you are my nephew makes me feel so glad." 32 Here, Woodson alludes to the white male practice of addressing black women in the familiar voice; whereas white women were treated as "ladies," black women were simply female. ${ }^{33}$ Along similar lines, Woodson notes, "Another . . exploiter in charge of a Negro college never wears his hat on the campus. His confidential explanation is that he might have to lift it when he meets a Negro woman." 34 Thus, Woodson views these slights to the femininity of black women as evidence of racism. Unlike white women, who were placed on a pedestal in the minds of white Southern men, black women were not viewed as objects of idealization. From our contemporary perspective, where we think it desirable for all females to be considered "women," this is an intriguing 
detail, and it offers us a view into turn-of-the-twentieth-century discourses on the role of black women. Regardless of what conclusion we reach, the fact that Woodson has noticed gender and race difference together adds to the richness of his historical treatment.

In a sweeping series of works written between 1934 and 1969 and covering black colleges from 1860 through 1960, Dwight O. W. Holmes discusses the myriad entities involved in the formation of these institutions, including the federal government, missionary organizations, Southern whites, and white male industrial philanthropists. ${ }^{35}$ Of significance is the credit Holmes gives to blacks for supporting their own colleges and schools: "the Negroes eagerly gave of their scanty funds to aid in the promotion of the schools." ${ }^{36}$ Although Holmes spends ample time discussing the student bodies of the black colleges and providing enrollment figures, he neglects to discuss the female students or to provide a gender breakdown in his statistics throughout the articles and monograph. Like Woodson, Holmes often uses the word men to generalize about "men" and "women," as was common at the time.

Much like Woodson's history of black education prior to 1861, Horace Mann Bond's The Education of the Negro in the American Social Order (1966) concentrates mainly on primary and secondary education, including only one chapter on higher education. ${ }^{37}$ Of note is Bond's pointing to the racial and gender makeup of the first student body of Howard University. In Bond's words, "There were no eligible Negro students at Howard University when it opened in 1869, and the first class was made up of five young white women, all of whom were daughters of local trustees, and two white boys from Louisiana." 38 Aside from this, there is no mention of gender relations or the experiences and contributions of black women. The majority of the discussion throughout the book is again focused on the relationships between white male industrial philanthropists and either the white male college presidents or on rare occasion, a prominent black intellectual such as W. E. B. Du Bois or a black leader such as Booker T. Washington.

Henry Bullock's A History of Negro Education in the South from 1619 to the Present, published in 1967, spans all levels of education, including significant discussion of black colleges and their development. Bullock emphasizes the role of white and black men in the creation and growth of these institutions and discusses the relationships and struggles between these men. When he does mention women, it is to discuss some of the early social experiments promoted by white industrialists to train black women in the industrial arts. Bullock examines teacher training and nursing but neglects to discuss the role and experiences of female students on campus; instead we are left wondering who these black women are. ${ }^{39}$

In a 1981 article titled "Northern Philanthropy and the Emergence of Black Higher Education: Do-gooders, Compromisers, or Co-conspirators?" Stephen J. Peeps examines black aspirations toward and white responsibility for higher education during the post-Civil War period. ${ }^{40} \mathrm{He}$ explores the history of black colleges in an attempt to explain why, according to critics, these institutions "lag so far behind their white counterparts." ${ }^{41}$ He wonders why 


\section{Gasman}

black colleges, "born of strong philanthropic sentiment," have not been more successful and posits that perhaps these white Northern philanthropists did not have the best interests of blacks in mind when they decided to support their education..$^{42}$ Peeps crafts a convincing argument, relying exclusively on secondary sources but neglects to discuss black women even when he examines curricular issues. As his title indicates, the focus of this article is on the white male industrial philanthropists.

James D. Anderson, in his now classic work The Education of Blacks in the South, 1860-1935 (1988), provides riveting analysis of how philanthropy and capitalism shaped early black education. ${ }^{43}$ In pursuing this topic, Anderson delves deeply into the cross-race relationships of the men involved with black colleges and black education in general but neglects to tease out any gender issues pertaining to administrators, students, or external constituents. He mentions women only a few times throughout the still remarkable book. For example, Anderson tells of Elizabeth Sparks, a "rebel slave" who participated in secret meetings in the slave quarters in which free blacks taught slaves to read. ${ }^{44}$ He also notes that black women were an instrumental part of the South's labor force and offers telling statistics on the number of black women providing labor. Although this information is not about black colleges in particular, it presents a foundation for Anderson's arguments later in the book. His most extensive discussion of gender appears in the chapter on the "Hampton model" of black education. The nineteenth-century brainchild of Hampton University principal Samuel Chapman Armstrong, the Hampton model refers to the idea and practice of training ex-slaves in agriculture and industry so that they would gain the skills needed for economic advancement in the South. ${ }^{45}$ Anderson examines the role of males and females in the Hampton model, noting that females received less regular training than their male counterparts and were encouraged to learn only domestic skills such as sewing, ironing, scrubbing, washing, and mending. ${ }^{46}$ Of particular interest in his discussion of Hampton, is the perspective of Roberta Whiting, the mother of one of the Hampton students. Instead of sitting by passively as her son was instructed in the fine art of milking cows, Whiting wrote a letter to the Hampton administration questioning why her son was not attending school but instead working. Through the inclusion of this story, Anderson demonstrates the assertiveness of black women and the concern they had for the education of their children.

Johnetta Cross Brazzell, the only black female writing in this category, wrote an article in 1992 titled "Bricks without Straw: Missionary-Sponsored Black Higher Education in the Post-Emancipation Era." ${ }^{47}$ Her research focuses on the white Northern missionary philanthropists and their efforts to shape black higher education. She uses Spelman as a case study and highlights the role of the early white female presidents. Although Brazzell examines education for black women, she draws upon the work of Thomas Woody to frame her discussion. This seems to be an odd choice, as Woody's work focused on white women. ${ }^{48}$ Brazzell uses Woody's ideas to explain the dual role that black women had to play during the period immediately following 
the Civil War, noting that they were "on the one hand, seen to have the same responsibilities as [w] hite women as it related to the moral development of the family. But in addition to being responsible for hearth and home, they were also expected to be full participants in that material world dominated by men. They were expected to earn their bread and make it too."49

Brazzell includes discussions of industrial education in her treatment of Spelman, noting that most of the black female students took industrial classes but few majored in this area; instead, they chose to pursue degrees in the classical liberal arts. She gives the reader a window into the curriculum at Spelman College but mentions little about the daily lives of the black female students. Similarly, Brazzell includes only one paragraph on the faculty at the institution, observing that in 1910, there were forty-two "[w]hite females and 7 [b]lack females. There were no male teachers of either race." Of interest here is Brazzell's comparison of Spelman's faculty makeup with that of Atlanta University and Morehouse College (at the time Atlanta Baptist College). She found that the coed institutions were more diverse in terms of racial and gender composition. ${ }^{50}$ Although much of the focus in Brazzell's article is on the white missionaries and the white leadership of Spelman, she is one of the few authors writing on the history of black colleges and outside control, who points the reader in the direction of black women.

In 1999, Eric Anderson and Alfred Moss published Dangerous Donations: Northern Philanthropy and Southern Black Education, 1902-1930. Their book tackled many of the same issues as James D. Anderson and examined many of the same male leaders. However, they took issue with some of Anderson's conclusions and called for a more nuanced interpretation of the primary sources. ${ }^{51}$ Anderson and Moss included a short discussion of the role of women in black schooling through an exploration of the Anna T. Jeanes Fund. ${ }^{52}$ However, here the examination of women is focused on teachers at the primary and secondary school level rather than in the black college environment. The authors do note that by the early twentieth century, many black women entered the teaching profession and in fact, outnumbered white female teachers in black secondary schools. Anderson and Moss also include a short anecdote about Anna Julia Cooper, focusing on her firing from St. Augustine's Normal and Collegiate Institute. Cooper was popular among blacks for her writings, teaching, and activism against racial discrimination and for women's rights. As such, members of the black press were outraged when the white head of St. Augustine fired her for "incompatibility of temperament." 53 This incident was cited as one of a number of examples of the white control of black education and the problems created by the absence of blacks in leadership positions. It was, however, not specifically included to illuminate the role of black women.

Anderson and Moss talk briefly, in a chapter providing an overview of black education, about the strict Victorian codes of behavior that were the norm at most "academic and industrial" schools. "Students were discouraged from all forms of unsupervised association between females and males. Dress, language, and manners that deviated from a 'genteel,' 'Christian' norm 


\section{Gasman}

were both unacceptable and grounds for dismissal." ${ }^{54}$ While this discussion highlights the restrictions placed on black women and men by whites, it does not interrogate the interactions and relationships between black men and women and neglects to question within-race patriarchy that black female historians have unearthed. ${ }^{55}$

Like these aforementioned books, William Watkins's White Architects of Black Education, 1865-1954, written in 2001, aims to explore and explain the actions of the white male philanthropists involved in the building of black education and black colleges. ${ }^{56}$ Watkins focuses each of his chapters on an individual white male industrialist; he makes no mention of how these individuals might have interacted with women, including black female administrators, students, or faculty. In Watkins's gendered history, the only relationships we see are those between men and other men.

For the most part, the histories in this category are male centered and treat black women as if they were not present at black colleges despite ample data that contradicts this notion. The authors tend to paper over the contributions of black women and ignore the realities of gender difference and how it might have played out during the creation of these colleges. Were black women involved in leadership roles or faculty positions at black colleges? Did they agree with the male presidents of their institutions on issues of governance and curriculum? Did black women approve of the often close institutional ties to industrial philanthropists? How were black women involved in the building and growth of institutions? What kinds of sacrifices did black women at black colleges make for the good of their race? When we study racism at black colleges, does it become difficult to confront the patriarchal structures within these institutions at the same time?

\section{Internal Campus Relations}

While one body of literature covers the founding of black colleges, another focuses on life on black college campuses. This literature tends to be jointly rooted in history and sociology. In discussing campus life, curriculum, and the extracurriculum, these authors sometimes touch on race, sometimes on gender, but rarely the intersection of the two. Daniel Thompson falls into this category and penned a nearly comprehensive text in 1973, Private Black Colleges at the Crossroads. Thompson meticulously included chapters on faculty, administration, students, and trustees, making sure to anchor the chapters in a rich sociohistorical setting. He also explored both the curriculum and governance structures at black colleges, making predictions for the future. Although gender is hardly mentioned in the book, there is a clear point of view: male. The reader is left to believe that the presidents and other senior leadership are male because their gender is not named. At certain points in the book, however, Thompson does provide context and statistics related to gender, offering commentary that is constrained by either his own sexism or that of those he interviewed as experts for the book (a panel of fifteen men and one woman). It could be argued that in the early 1970s, Thompson's inclusion 
of a female on his panel of experts was indeed progressive and critiquing him for his lack of inclusion of women would be unfair. However, I would hold that this is not the case. The country was in the midst of the women's movement and at the tail end of the civil rights movement. Throughout this period, black women were active and visible (yet still overlooked by both white women and black men in the aforementioned movements). ${ }^{57}$

When discussing the student body makeup at private black colleges, Thompson gives the following explanation for why it is 60 to 70 percent female: "This resulted from complex social forces - the strong feminist attitude of the [b]lack matriarch, discrimination in employment, [and] lack of a sufficient number of stable male symbols of success." ${ }^{8}$ In the words of Jean Carey Bond and Patricia Perry, both black nationalists, "in reality [b]lack women, domineering or not, have not had the power in this male-dominated culture to effect a coup against anyone's manhood-in spite of their oft-cited economic 'advantage' over the [b]lack man." 59 The authors are more than likely alluding to Daniel Patrick Moynihan's 1965 report titled The Negro Family: The Case for National Action and E. Franklin Frazier's Negro Family in the United States, published in $1951 .{ }^{60}$ Both of these publications discussed the so-called black matriarchy and caused a stir in black communities upon publication.

With regard to faculty composition at black colleges, Thompson claims that faculties had becoming increasingly female by the 1960s. His theory as to why black colleges had seen an increase in female faculty is that it was cheaper to employ them. As evidence for this claim, Thompson states that black women were willing to accept lower salaries because they had to move for their husbands. Specifically, Thompson notes,

The bargaining power of prospective female teachers is quite weak even if they rank high in [quality]. This is often due to a common situation whereby a husband, for example, accepts a position in a city and his wife, as is socially and legally expected, accompanies him. As a university trained person, she may have no opportunity for satisfactory employment in the new community except at a given [b]lack college. Therefore, her bargaining power is compromised. Such women often accept teaching positions in [b]lack colleges despite the very low salaries offered them. ${ }^{61}$

Although Thompson's statement shows an understanding of theories of feminized labor and even sympathy for the black woman's point of view, his overall slant is troubling. ${ }^{62}$ Drawing upon his majority-male panel of experts, Thompson expounds upon the impact of a mostly female faculty, opining that their increased presence produced "a decline in the overall quality of the faculties" at black colleges. ${ }^{63}$ As evidence, he cites the fact that many of the female faculty members were recruited merely because they were "easily available and not because they were deemed to be the most promising professional prospects." 64 While Thompson admits that some of these black women excelled, he notes that most simply held "their jobs from year to 


\title{
Gasman
}

year," performing their "professional roles in a more or less routine, lackadaisical manner." 65

Attempting to "sum up" the performance of black female faculty members and to provide an authoritative opinion on the matter, Thompson quoted a black male department head, who said,

\begin{abstract}
They are forever housewives or society matrons. The female dimension of their personalities is always dominant. Even in the most formal academic situations they behave more like housewives than skilled professionals. Most of them shy away from any duty or involvement that might interfere with family affairs. ${ }^{66}$
\end{abstract}

Thompson slightly mitigates this portrayal by noting "conversely, some of the most unambitious, effete teachers are male." ${ }^{67}$ Unlike the black women, though, these unambitious men somehow escaped Thompson's rebuke for the decline in academic quality of black colleges. After reading Thompson's portrayal of black female faculty, we are left wondering why he did not interview them or draw upon resources that captured their experiences. Where is their voice? Would he have reached different conclusions had he talked with black women?

A more balanced portrayal of black female faculty members and their academic spouses can be found in Linda Perkins's "For the Good of the Race: Married African-American Academics-A Historical Perspective"-located in a contemporary book on academic couples. ${ }^{68}$ Here, Perkins focuses on the historical differences in gender roles within the black community, as compared to those of the larger society. Furthermore, she examines how these differences had an impact upon African American academic couples. Of significance is her discussion of the development of faculties at black colleges, including Howard, Fisk, Lincoln, Wilberforce, Morehouse, North Carolina Central, and Tennessee State. She notes that unlike white women who were routinely asked to forfeit their positions upon marriage, black women working at black colleges held on to their positions. Where Thompson blames black female faculty members for their own lack of advancement, Perkins notes that the doctoral degree, which was difficult for black women to obtain, became the main roadblock to upward mobility. Between 1876 and 1926, for example, out of the fifty African Americans to secure doctoral degrees, only four were female. According to Perkins, "The separate black college, which was primarily an outgrowth of society's mandated segregation of African Americans, ironically resulted in professional opportunities for African American women that were often unavailable to other women." ${ }^{\circ}$

Thompson's final discussion of gender disparities focuses on trustees and presidents. He is brief in his examination but notes that despite the large majority of female students and faculty in black colleges, the trustees remain almost entirely male, with most black colleges having virtually no female trustees at all during the 1960s and early 1970s ( 5 percent of trustees were female in black colleges). Thompson also astutely points out that even Bethune-Cookman 
College, an institution founded by "a great [b]lack female educator and leader," Mary McLeod Bethune, did not have a single female trustee. ${ }^{70}$ At all-female and all-black institutions, such as Spelman and Bennett colleges, women made up half of the trustees. Given the mostly white and mostly male makeup of the black college boards of trustees from their beginnings through the early 1970s, it is not surprising that black women have rarely served in the role of president. When asked to describe the typical and optimal black college president, the trustees interviewed by Thompson expressed the view that the president should be male. As Thompson explains,

The policy regarding the sex of the president is generally tacit yet quite rigid. Most trustees insisted they would accept a female president if she was the best qualified candidate, yet none of the trustees interviewed had ever recommended a female candidate. ... At present, all of the presidents of the better known [b]lack colleges (even the two women's colleges) are male. ${ }^{71}$

Of note is the fact that one of the two women's colleges, Bennett College, did in fact have a black female president earlier in its history: Willa B. Player, who was inaugurated in $1956 .^{72}$ Although she was not president when Thompson wrote his book, she held the post until 1966, when she became director of the Division of College Support in the U.S. Office of Education at the Department of Health, Education, and Welfare. ${ }^{73}$ During her tenure at Bennett, Willa Player was continually asked to justify the existence of a black women's college, as very few people saw the value in separate education for black women. ${ }^{74}$ It would not be until 1987 that Spelman College, arguably the more prestigious and best known black women's college, would have a black female as president. That individual was Johnnetta B. Cole. ${ }^{75}$ In fact, Spelman did not have a black female dean until the 1970s during the presidency of Albert Manley. ${ }^{76}$ Within the black college community, which was primarily governed by white and black male trustees, black women were rarely trusted to lead their own kind. ${ }^{77}$ Thompson provides some analysis of the gender relations on black campuses. However, his discussion of gender (for example, the valuation of black women's labor, the judgment of the quality of their teaching, and their absence from the ranks of administration) rarely makes reference to the race of the women in question. Many of these problems would apply equally to white women at the time.

Another book that falls into the category of internal campus relations and which was written shortly after Thompson's work is Raymond Wolters, The New Negro on Campus: Black College Rebellions of the 1920s (1975). Wolters focuses on the uprisings that took place on some black college campuses. Although he keenly describes the students' motivations for rebelling against the campus administration and includes an occasional black woman in an example, the book does not differentiate gender. Wolters spends considerable time talking about the influence of black intellectuals and luminaries on the thought process of the black college students-but with few exceptions, these intellectuals and luminaries were black men. ${ }^{78}$ 


\section{Gasman}

Although it advances the study of history, Henry Drewry and Humphrey Doermann's Stand and Prosper: Private Black Colleges and their Students (2001) spends little time examining the roles and contributions of black women. Drewry and Doermann begin their book with an overview of the freedmen school, a precursor to the black college. With regard to the race and gender of its staff, the authors note,

A typical teacher in a freedmen school during the decade following the Civil War was a well-educated, white, middle-class, Protestant woman from New England. The presidents of the early colleges fit the same profile except that all were men. ${ }^{79}$

Drewry and Doermann acknowledge that there were a few Northern black female teachers, giving Charlotte Forten as an example. Born in Philadelphia in 1837, Forten taught at a school in Massachusetts before moving South in 1862. She stayed for only two years, as the experience was not what she imagined-the students were in her words "babies" and she considered writing home to "ask somebody to send [her] picture-books and toys to amuse them." 80

Although the authors of Stand and Prosper consider some gender disparities, they ignore gender and women in the discussion of the influence of black intellectual currents and of civil rights activities on or near black college campuses. For example, Drewry and Doermann examine and even provide a chart listing the prominent intellectuals and artists hailing from black colleges-but, like Raymond Wolters, omit black women completely. Luminaries and scholars such as Zora Neale Hurston, Charlotte Hawkins Brown, Anna Julia Cooper, and Lucy Diggs Slowe_-all black college graduates_-are overlooked. ${ }^{81}$ As historians Linda Perkins and Patricia Bell-Scott have demonstrated, black women such as Lucy Diggs Slowe made significant contributions within the halls of black colleges and beyond. ${ }^{22}$ Slowe, the first Dean of Women at Howard University (1922-1937), was a powerful and groundbreaking leader within the black college community as well as within higher education in general. She challenged the exclusion and underrepresentation of black women at Howard, especially within the institution's policy-making bodies. ${ }^{83}$ Moreover, she took public stands at the university, speaking out on gender-based salary discrimination and demanding equal living conditions for women. For example, in an article from the 1930s, Slowe described her frustrations with the lack of input allowed on the part of students, especially women, to "participate in the making and executing of the rules under which they live." ${ }^{84}$ Her bold demeanor angered many of her black male peers, who were used to being openly condescending to black women. In one instance, when Slowe stood up for several black female students who had been sexually harassed by a black male professor, she received a letter attacking both her credibility and that of the students. ${ }^{85}$ The accuser asserted, "You forget that you are merely the Dean of Women and not the custodian of morals of the male teachers of Howard 
University. It is my opinion if you had something to do and two classes to teach as the other Deans, you wouldn't hear so much." 86

Lucy Diggs Slowe's views on empowering black women did not gain favor with then Howard University president Mordecai Johnson. ${ }^{87}$ A graduate of allmale Morehouse College, Johnson hired black women for the faculty but held to his paternalistic views. ${ }^{88}$ In Slowe's words,

From the time this case [i.e., the sexual harassment incident] happened down to the present, I have not had the cordial support of the President. When the time came to raise salaries, he raised mine $\$ 200$ and raised other Deans with qualifications no better than mine in amounts ranging from $\$ 850$ to $\$ 1,150 \ldots$. He, without explanation, ex[c]used me from his conferences with the Academic Deans, although prior to 1930 the Dean of Men and the Dean of Women had sat with the Board of Deans. He has never sympathetically studied the real work of the Dean of Women, and still seems to have a wrong conception of her function. He confuses her with a matron. . . I have tried in every way to correct this but can get no co-operation from the President. 89

From the time that Mordecai Johnson arrived at Howard in 1926 until Slowe's death in 1937, they quarreled over issues of equality for black women. In fact, in 1933, Slowe wrote an open letter to the executive committee of the Howard University board of trustees recounting the inferior conditions and ill treatment that she had to endure..$^{90}$ According to Patricia Bell-Scott, who unearthed much of Lucy Diggs Slowe's correspondence and administrative work, the letter sent to the board of trustees "provides testimony to the courageous battle one woman waged on behalf of [b]lack women in the academ[y]."11 As black leaders gradually supplanted whites in the presidential offices, they sometimes continued the domineering leadership styles of their predecessors. This remained a problem through the 1960s and '70s. Although there have not been any empirical studies in this area, individual testimonies abound regarding the difficult situation black women faced under autocratic and black male-dominated leadership. For example, in a painful report of the years she spent at black colleges titled "Black Women in Academia," Margaret Walker Alexander points, in particular, to her days at Livingstone College in North Carolina and Jackson State University in Mississippi. According to Alexander, every time she succeeded in making a creative contribution within these institutions, she was replaced by a black man. The institutions' presidents constantly questioned her intelligence and dedication. ${ }^{92}$ Unfortunately, the oppressive styles of some black college presidents and their unfair treatment of black female faculty have been used by white outsiders to demonstrate the inferiority of black colleges in general..$^{93}$ This has made it difficult to raise questions about leadership at black colleges without engendering charges of racist complicity with these institutions' outside detractors. However, as black women who have actual experiences with these problems have come forward with 


\section{Gasman}

more nuanced accounts, it has become easier to offer a balanced critique of black male leadership. ${ }^{94}$

Despite providing a detailed description of the role of black college students in the civil rights movement, Drewry and Doermann overlook the actions of black female civil rights activists. ${ }^{95}$ In their brave book Gender Talk, Cole and Guy-Sheftal describe the typical, womanless depictions of the $1960 \mathrm{~s}$ as "The Masculine Sixties." They point to the words of key civil rights and Black Power leaders, noting the sexism that lay buried in their outlooks and mantras. For example, Cole and Guy-Sheftal's analysis of the ideologies of Imamu Amiri Baraka (formerly LeRoi Jones) and Maulana Ron Karenga, founder of the Los Angeles-based organization US, shows that each man envisioned a submissive role for black women. The authors point to the blatant disregard that mainstream civil rights organizations and their black male leaders had for black female students at black colleges, despite the heroic efforts of these women. It should be noted that some black women denied being oppressed during the civil rights movement. Cole and Guy-Sheftal acknowledge this and cite the following examples: "At a SNCC [Student Nonviolent Coordinating Council] reunion conference at Trinity College in 1988, Jean Wheeler Smith asserts, 'I wasn't subordinate, I was high functioning. I did anything I was big enough to do...' She indicated that while Stokely [Carmichael] might have wanted to be a male chauvinist, he just wouldn't have been able to get away with it, given the strength of the black women around him like Ella Baker, Fannie Lou Hamer, Victoria Gray, and Ruby Doris Smith-Robinson." 96

Although rarely discussed, during the 1950s and early 1960s, black women on black college and university campuses were instrumental in the civil rights protests. Women at both Bennett and Spelman colleges participated in sit-ins and lunch counter demonstrations. ${ }^{97}$ The administrators of these black women's colleges, who by this time were black rather than white, were oftentimes supportive of the students' actions. ${ }^{98}$ For example, as student demonstrations escalated at Bennett College in Greensboro, North Carolina, President Willa Player was under pressure by the local white establishment to curb the actions of her students. She refused and continued supporting the students' efforts. She also kept her board of trustees informed and reaffirmed her stance regarding student demonstrations. In a 1960 letter to the board, she wrote, in their defense:

These protests have been orderly and dignified. The reason for them is crystal clear to all of us who are deeply involved in the struggle for human dignity and equality of opportunity. We see them as new and well-informed young leadership which is fearless and determined. ${ }^{99}$

However, this type of support was not the case at all black colleges and universities. At some public black institutions, which were under the close supervision of state government authorities, and even a few private institutions, administrators declined to help both male and female student protesters who 
had landed in jail. ${ }^{100}$ Many of the young black college women involved in the movement showed great courage, working diligently to make change within their communities and within the country as a whole. ${ }^{101}$ For example, Barbara Harris and Diane Nash, both Fisk University students, were jailed along with sixty-three other male and female students who protested Nashville's segregated lunch counters. Although they were offered an opportunity to make bond (\$100), they chose to go to jail because in their minds, paying the bond would have been a capitulation to the South's Jim Crow government. ${ }^{102}$ Ironically, as these female students were fighting on behalf of civil rights, they were still being treated as fragile accessories to men by their college administrations. For example, at the same time that the aforementioned students at Bennett College were marching in the streets and attempting to desegregate lunch counters, they were required to take a course called the "The Art of Living," that focused on becoming a successful homemaker. ${ }^{103}$

In their discussion of student protest at Spelman College during the mid1970s, Drewry and Doermann acknowledge the agency of black female students in their fight for a black female president. From its beginnings through 1953, four white women led the all-black women's college. In 1953, Albert Manley, the former dean of the College of Arts and Sciences at North Carolina College, became the first African American and first male president of Spelman. When Manley resigned in 1976, the alumnae and students had high hopes that the institution's board of trustees would choose a black woman to lead the highly respected black women's college. Instead, the board chose Donald Stewart, an African American man, who was educated in the North and had worked with the Ford Foundation. ${ }^{104}$ Drewry and Doermann capture the frustration of a female student group, who in protest locked the board of Trustees in the campus's main administration building-forcing the administration to negotiate for their release. Despite the campus uproar, the board held to its decision to bring in Donald Stewart. In the end, the students were welcoming and hospitable to him and his family upon their arrival to Spelman. As mentioned earlier, Spelman would not appoint a black female president until 1987, when it hired Johnnetta B. Cole. Not only was Cole the first black female to hold the post; she was the first academic. Moreover, it would not be until 1997 that Spelman would hire an alumna. Audrey Manley, the wife of former president Albert Manley, was appointed to the post after serving as deputy surgeon general of the United States. ${ }^{105}$ Thus, Drewry and Doermann provide an in-depth analysis of the struggles and contributions of black women at Spelman College in the 1970s but little about black women in other black college contexts. Because we do not see black women as actors within male-dominated contexts (e.g., a coed black college), this has the effect of obscuring the intersection of race and gender.

The most recent attempt at providing a broad overview and history (in part) of black colleges is the mainly celebratory, general-readership book I'll Find a Way or Make One: A Tribute to Historically Black Colleges and Universities (2004) by Juan Williams and Dwayne Ashley. ${ }^{106}$ This text spends a considerable amount of time addressing gender differences and the role and 


\section{Gasman}

actions of black women at black colleges. Although the authors present much of their information in short vignettes, they manage to include a great deal of material on what has been written on black women at black colleges, giving the reader a broad overview. For example, in their synopsis of the establishment of Spelman, they describe the role of black women. Williams and Ashley also discuss the curricular and extracurricular choices offered to black women throughout the history of black colleges, providing interesting, albeit brief, descriptions of everything from sewing classes at Bethune-Cookman College to the rifle club at Talladega College to sorority membership at Howard University. ${ }^{107}$

Perhaps the most interesting discussion and inclusion of black women in the book is in the authors' depiction of Mary McLeod Bethune. Considering the fact that she founded a black college, was the first African American female president of a black college, and had close ties to white philanthropists, the scant coverage that she receives within the literature on the history of black colleges is especially puzzling. ${ }^{108}$ In 1904 , she started the Daytona Educational and Industrial Training School for Girls in Florida. The institution, now known as Bethune-Cookman College (1923), is in fact, the only black college in the nation founded by an African American woman. Williams and Ashley credit Bethune with shifting the missionary-black college paradigm, noting that "instead of receiving assistance from missionaries, the school and its African American students became missionaries to the surrounding community." 109 Moreover, the authors provide evidence of Bethune's role in stabilizing the community surrounding the college as the nation entered and recovered from World War I. She served as a strong leader of the institution for forty years, bringing the cause of African American higher education to the attention of the nation's political and business leaders. Although most people in Daytona Beach, where the college was located, thought she would not succeed and the school would fold, Bethune worked diligently, and her efforts and charisma attracted the attention of James Gamble, cofounder of Proctor \& Gamble. Gamble supported Bethune's college for years and served on the board of trustees. ${ }^{110}$ Williams and Ashley's treatment of Bethune is significant because it provides a lens through which to view the effect of both race and gender in a black college philanthropic relationship. It is unfortunate that we have to rely on what amounts to a coffee-table history of black colleges for an extensive discussion of Bethune's contributions to black colleges and philanthropic ties.

Scholarly literature on black college campus relations omits black women's involvement in the civil rights movement and fails to recognize their intellectual contributions to black colleges and society at large. When black women are discussed, they are often described as a drag on the quality of the curriculum and the institution as a whole.

\section{Black Women's Higher Education}

Few histories are specifically devoted to the experience of black women at black colleges. As such, most accounts of black women's lives at these 
institutions occur in more general works in the field of African American history. Because these histories were written either before or about a time in the United States when black women were not admitted in any substantial number to historically white institutions, the majority of the discussion in them is about the black college context. ${ }^{111}$

During the early years of black colleges, black female students were sheltered by the administration; their lives were shaped by institutional policies designed to control their behavior. In the eyes of the white female missionaries, black women had been stripped of their feminine virtue by the experiences of slavery and as such had to be purified before they could assume the responsibilities of the home. ${ }^{112}$ Typically, during the late 1880 s, female black college students were not allowed to leave the campus without a member of the administration escorting them. By contrast, men were free to come and go as they pleased. At most institutions, the dean of women lived on campus in order to watch over the "fragile" and "impressionable" young college girls. The dean of men, on the other hand, lived off campus, as did the other upper-level administrators. ${ }^{113}$ During the mid-1920s, many female students at black colleges and universities urged campus administrators to grant them greater autonomy, noting that it would help them learn self-reliance-a skill that they saw as essential to assuming leadership roles. These same black women fought vehemently against the repressive religious customs used to bring up their race and gender. These practices were generally imposed by white and black male administrators, many of whom were also ordained Baptist ministers. In particular, the administrators would often cite the religious doctrines of St. Paul as an excuse to relegate women to second-class status. Black women were told that, according to the Bible, patient waiting was to be held above the development of one's talents. ${ }^{114}$

Perhaps the seminal work on the history of black women's higher education is Jeanne L. Noble's book titled The Negro Woman's College Education-written bravely in 1956. ${ }^{115}$ Noble wrote one of the first books to comprehensively cover black women's higher education in both the black college and historically white setting. Unlike many of the more male-oriented histories of black education, Noble considers race and gender together. She notes that "the education of Negro women during this period was prompted particularly by one factor - the realization by benefactors and freedmen alike that there was an increasing need for Negro teachers." The mass of newly freed blacks needed "at least a rudimentary education . . . to progress in the culture." ${ }^{116}$ Noble also spends considerable time discussing the popular views of black women, noting that there was great controversy over their mental and physical abilities. This controversy resulted in a decision to forgo educating them in the "high arts." According to Noble, "Some critics held that it was most necessary that [black women's] education be grounded in moralistic and character training. Interestingly, none went so far as to say "her place is in the home."'117 Noble also argues that "moral education" was typically religious in nature and was traditionally enforced through the use of strict rules and regulations. She further explains, about the curriculum at black colleges, 


\section{Gasman}

it appears that many of the Negro woman's rules and regulations may possibly have been predicated on reasons relating to her foremother's sex role as a slave. Over night she was to so live that by her ideal behavior the sins of her foremother's might be blotted out. Her education in many instances appears to have been based on a philosophy which implied that she was weak and immoral and that at best she should be made fit to rear her children and keep house for her husband. ${ }^{118}$

Here, we have one of the first attempts to analyze the joint effect of race and gender. As mentioned earlier, black male students were not held to such strict standards; the defense of their virtue was seen as less critical. Thus, racism and sexism intersect: racism says that black women were less virtuous than white women; sexism puts responsibility for sexual conduct on black women. The result is a form of double jeopardy or the double oppression that Beverly Guy-Sheftal discusses in her anthology, Words of Fire. ${ }^{119}$

With an eye toward comparison of the situation of black women in black colleges and historically white institutions, Noble found that black female graduates of historically white institutions were "less utilitarian and more liberal-arts minded" than the graduates of black colleges. ${ }^{120}$ Noble concluded her discussion of black women by predicting that they would be called upon to provide leadership in many areas, including education, the community, and politics.

Another work of significant importance is Patricia Bell-Scott's "Schoolin' 'Respectable' Ladies of Color: Issues in the History of Black Women's Higher Education" written in 1979. ${ }^{121}$ In this article, Bell-Scott discusses the early education of black women, noting that most black women were trained to be grammar school teachers. She used three guiding questions to approach her research, which are still important today: (1) Should the higher education of black women be separate or coeducational? (2) Should the educational curriculum for black women be different from or similar to the curriculum in institutions that are predominantly male or white? (3) Do black women have special, psychosocial needs that must be considered by educators? ${ }^{122}$ BellScott provides an overview of the early black women's colleges, noting that Bennett College began as a coeducational institution and Barber-Scotia was originally all female. Of particular interest is the link that she makes between industrial education, a heavily covered subject in the history of black colleges, and home economics. Discussing the institutionalization of home economics at black women's colleges, she notes, "both Spelman and Bennett developed formal home economics curricula in the 1920's." ${ }^{23}$ In 1927, only one year after its shift from coeducation to all-female education, Bennett College organized a nursery school, a parent education center, and a homemaking institute. A surprising factor in the black college picture (and one left out by many other books) was the long days and heavy work schedule imposed upon the black female college students-which Bell-Scott notes was a part of a commitment by the college to training domestic women. ${ }^{124}$ 
Rita Liberti, beginning in 1999 with "'We Were Ladies, We Just Played Like Boys': African American Womanhood and Competitive Basketball at Bennett College, 1928-1942," has explored the experiences of African American women in sports at black colleges. Although the majority of this article and the subsequent book chapters written by Liberti are concerned with the specifics of sports and institutional rivalries, she does provide keen insight on student life at black colleges, especially within intercollegiate and intramural sports. ${ }^{125}$ She demonstrates that in the 1920s and 1930s, black colleges were supportive of women participating in competitive sports such as basketball; however, by the 1940s, most black colleges moved their female athletes to less competitive sports, such as badminton, due to concerns over female students' "womanhood." Liberti points to the ironies of life for black female students at Bennett College in particular, noting that "while Bennett officials created an environment that supported acts of civil disobedience in protest of racial injustice," they demanded that students act according to norms of feminine behavior. ${ }^{126}$ Unfortunately Liberti's work is all published in sports-oriented outlets and as such has been overlooked by those interested in understanding the history of gender among students at black colleges.

Yolanda L. Watson and Sheila T. Gregory's recent book Daring to Educate: The Legacy of the Early Spelman College Presidents (2005) is one of the first books that focuses specifically on women students and faculty at black colleges. However, it should be noted that a good portion of the book highlights the impact of the early white presidents of Spelman College. Because Spelman did not have a black female president until 1987, the authors think it is essential to discuss this history of white female involvement as president. Of note is the way that Watson and Gregory contextualize the work that early presidents Harriet Packard and Sophia Giles did with the black female students at Spelman. The authors include a chapter summarizing higher education for African American women. Using an approach informed more by sociological theories than historical interpretation, the authors spend time discussing the differences in motivations for educating black and white women. In their words, black women were educated for "short-term escape from sexual subjugation and long-term social subjugation" within the nation; whereas white women were educated to "establish social parity with men." ${ }^{27}$ Of course, some white feminists would disagree with the portrayal of white women offered by Watson and Gregory; educating white women for "social parity" may be a bit of an oversimplification.

Watson and Gregory also include a section in their book on the differences in curriculum for black and white women. According to the authors, white women, especially those in women's colleges in the Northeast were encouraged to pursue study in the classics as well as the humanities and the sciences (not with the intention that they would become doctors, lawyers, and senators, of course). In addition, white women's college faculty emphasized the "ornamental" subjects of art, music, and elocution. Drawing heavily on the work of Linda Perkins, Watson and Gregory illuminate the differences in the curriculum for black and white women, noting that black women were 


\section{Gasman}

prepared for teaching and missionary work as well as the improvement of their race. ${ }^{128}$ According to some scholars, this kind of training gave black women in the early twentieth century more of a voice in their own communities than white women in theirs. ${ }^{129}$ Many educated black women became emissaries of education in their communities, while middle class white women, by and large, became well-educated housewives, imparting knowledge to their children. ${ }^{130}$ By asking the questions "what is the expected role of a female college graduate?" and "how does that role differ for black women versus white women?" Watson and Gregory grasp the combined effect of race and gender. Along with Noble and Bell-Scott, they are among the few historians writing on the topic of black colleges who do this.

The most recent book in this category is Stephanie Y. Evans's Black Women in the Ivory Tower, 1850-1954 published in 2007. ${ }^{131}$ Although the majority of this book, as suggested by the title, focuses on black women and their experiences at historically white institutions, Evans includes small sections on women's lives on black college campuses and explores the philosophical ideas of Mary McLeod Bethune. Relying mainly on secondary sources for the black college sections and for the most part Elizabeth Ihle's primary source anthology Black Women in Higher Education, Evans illuminates the mixed experiences of black women. ${ }^{132}$ She provides discussion on the black female students at Spelman and Bennett but of more interest, considering the scarcity of research on the topic, is her depiction of black women at coeducational black colleges. According to Evans, "for black coeducational colleges admitting women, administrative efforts to match student populations with course offerings were tumultuous at best." 133 In fact, when coeducational schools, such as North Carolina Agricultural and Technical State University, had to make decisions that pitted the interests of black male and female students against each other, the institutions would oust the female students. In the minds of many black male administrators, according to Evans, black females were "expendable" and a distraction to male students. ${ }^{134}$ These gender-based tensions are not addressed in the literature on the history of black colleges in general.

Like other historians, Evans discusses the strict codes of behavior for black women on black college campuses in more depth than any of the historical literature on black colleges. Relying once again on Ihle's anthology of sources, Evans notes that at some black colleges "modesty was promoted by enforcing a dress code that restricted jewelry, lace, and the types of dresses allowed." 135 She also quotes Hattie Kelly, a Tuskegee student in 1911, to emphasize the microscope under which black women at black colleges lived: "Your room was inspected, your trunks inspected, your closets, your clothes, everything was inspected and you were given demerits if everything wasn't just right." 136 When descriptions of black women's lives are included in the history of black college literature, they rarely include the voices of black women and tend to skim over the strict and oppressive nature of the campus rules. Through an exhaustive culling of secondary and some primary 
sources, Evans provides a more in-depth discussion of black female students at black colleges than all of the history of black college literature combined.

\section{Research Recommendations and Significance for Current Policy and Practice}

Speaking of previous scholarship in the field, Jeanne Noble began her book The Negro Woman's College Education with a profound statement: "Despite the fact that Negro women have a close affinity with women and Negroes, the reader has had to rely on footnotes and postscripts concerning them."137 Although a wonderfully rich literature has been written on the history of black women in general since the publication of Noble's book in 1956, her comments still apply to the subject of black women at black colleges. ${ }^{138}$ One must comb through histories of black colleges to find even the smallest example or discussion of women at these institutions. In articles and books related to the history of black women, black colleges are rarely discussed with any depth. Instead, the focus is on black women's access (or lack thereof) to historically white institutions_-an important topic, of course. ${ }^{139}$

Until recently, black and white men have written much of the literature on black colleges. Perhaps as a result, black women have been placed at the margins, their lives rarely explored. In effect, race has become masculine. The fact that, for black women, differences of race and gender are equally important has been ignored. Interestingly, much of what has been said about black women's experiences at black colleges covers only the all-female colleges, Bennett and Spelman. ${ }^{140}$ This literature is, with rare exception, written by African American women. Seldom do we learn of the lives of black women at coed black colleges. With regard to these institutions, the most basic questions have yet to be answered. Who were these women? What did they study? What activities did they participate in outside of the classroom? Who were the campus leaders? Was there gender discrimination, and how did it manifest itself in the classroom and on the campus? How were black women represented on the faculty, within administration, and among the student body? How did black women shape the missions and activities of coed black colleges?

Answering these basic questions will give us the background we need to explore more theoretical issues pertaining to women at black colleges. Can existing gender theories be applied to the lives of women at black colleges, or must we craft new theories to explain their unique experiences? Why were certain types of education and particular roles deemed appropriate for black college women? How does the treatment of black women at black colleges reflect a difference in how black and white women were seen in society? ${ }^{141}$ How have gender disparities played out at black colleges? ${ }^{142}$ A number of talented female historians have explored issues pertaining to African American women in higher education. ${ }^{143}$ We now need more research on the history of black women at black colleges_-research that contextualizes women's lives within the larger black college setting and that provides in-depth analysis of individual black women's actions. It is essential that such research on black 


\section{Gasman}

colleges discuss the special circumstances that result from the interlock of race and gender difference.

This historiography of black colleges and gender is significant for historians and nonhistorians alike; it has implications for educational policy and practice in the current day. As noted in this article, the use of the black male experience to stand for the experience of black women is problematic in research-but it is especially troubling in practice, as the unique situations of black men and black women may not be uncovered. For example, black colleges have a significant and highly touted track record for sending African Americans into graduate science programs; however, when one takes a closer look, gender disparities surface. black women are significantly more successful at the undergraduate and master's level, whereas black men have greater success gaining entry and persisting in science-related doctoral programs. ${ }^{144}$ As noted in this historiography, curricula for black women over time have been practitioner-oriented-preparing them for teaching, nursing, and public health positions. These positions typically require only bachelor's and master's level training. Could this explain, in part, why few black women are pursuing PhDs in the sciences? Policy makers, funding agencies, and higher education faculty and administrators should consider historical gender differences when crafting recruitment and retention efforts as well as when funding research.

It is revealing that the overwhelming majority of the scholarship written on black women and issues of gender at black colleges was written by African American women. We may never have learned of this history if these black women had not pursued such a line of research. This demonstrates the importance of drawing out the voices of those who have not been heard. Faculty and administrators throughout higher education should work to make sure that their institutions have diversity among those conducting research. Moreover, faculty members should not discourage students (as research tells us they often do) from pursuing topics related to personal experience, especially issues of race, class, and gender, as these areas are no doubt fertile ground for new ideas. ${ }^{145}$

Last, this historiography of black colleges and gender helps us to understand the importance of historical and cultural context in the research process. When scholars pursue research related to African Americans, they should remember that a deeper understanding of the historical context, considering the intersection of race and gender, can help to shape research questions as well as lend more legitimacy to the findings and implications of scholarship. ${ }^{146}$ The use of a dual lens as described in this article may shed new light on old issues.

\section{Notes}

Dr. Gasman was motivated to pursue this work upon discovery of the omission of gender in her own work on black colleges. She hopes that after reading this article, others will reconsider their scholarship and practice, particularly how they represent or omit issues of gender and race. This article was enriched by the helpful criticism offered by the anonymous reviewers of the American Educational Research Journal as well as its editor, Sandra Hollingsworth. Dr. Gasman would also like to thank the following individuals for 
reading earlier versions of the article and providing feedback: Linda Perkins, Laura W. Perna, Shaun R. Harper, Rachelle Winkle-Wagner, Barbara Banks, Valerie Lundy-Wagner, Pamela Felder Thompson, Wayne J. Urban, Sibby Anderson-Thompkins, and Edward M. Epstein. Last, she is most appreciative of Patricia Bell-Scott for sharing several primary sources that proved difficult to locate.

${ }^{1}$ Johnnetta Betsch Cole and Beverly Guy-Sheftal, Gender Talk: The Struggle for Women's Equality in African American Communities (New York: Random House, 2003), xxii.

${ }^{2}$ Cole and Guy-Sheftal, Gender Talk, xxii; See also Elsie Washington, Uncivil War: The Struggle Between Black Men and Women (New York: Noble Press, 1993); Toni Cade, The Black Woman (New York: Pocket Books, 2005); and Michelle Wallace, Black Macho and the Myth of the Superwoman (New York: New Left Books, 1999).

${ }^{3}$ Cole and Guy-Sheftal, Gender Talk, xii.

${ }^{4}$ Patricia Hill Collins, Black Feminist Thought: Knowledge, Consciousness, and the Politics of Empowerment (New York: Taylor \& Francis, 1999). bell hooks makes a similar statement in chapter 5 of her book "Ain't I a Woman": Black Women and Feminism (Boston: South End, 1981), 195.

${ }^{5}$ Evelyn Nakano Glenn, "The Social Construction and Institutionalization of Gender and Race: An Integrative Framework," in The Gender Lens: Revisioning Gender, ed. Myra M. Ferree, Judith Lorber, and Beth Hess (Thousand Oaks, CA: Sage, 1998), 3-15, 3.

${ }^{6}$ Cole and Guy-Sheftal, Gender Talk, xxii; See also Florence Bonner, "Addressing Gender Issues in the Historically Black College and University Community: A Challenge and Call to Action," The Journal of Negro Education 70, no. 3 (2001): 176-91; Beverly Guy-Sheftal, Words of Fire: An Anthology of African American Feminist Thought (New York: New Press, 1995); bell hooks, Yearning: Race, Gender, and Cultural Politics (New York: South End, 1990). See the following for more information on gender issues in the black community: Collins, Black Feminist Thought; Margaret Anderson and Patricia Hill Collins, eds., Race, Class, and Gender: An Anthology (New York: Wadsworth, 2006); Patricia Hill Collins, Fighting Words: Black Women and the Search for Justice (Minneapolis: University of Minnesota Press, 1998); Patricia Hill Collins, Black Sexual Politics: African Americans, Gender, and the New Racism (New York: Taylor \& Francis, 2005); Patricia Hill Collins, From Black Power to Hip Hop: Racism, Nationalism, and Feminism (Philadelphia: Temple University Press, 2006); Elizabeth Higginbotham, Too Much to Ask: Black Women in the Era of Integration (Chapel Hill, NC: University of North Carolina Press, 2001); Valerie Smith, Not Just Race, Not Just Gender: Black Feminist Readings (New York: Routledge, 1998); Beverly Burke, Andrea Cropper, and Philomena Harrison, "Real or Imagined: Black Women's Experience in the Academy," Community Work, and Family, no. 3 (December 2000), 297-310; Joy James and T. D. Sharpley-Whiting, eds., The Black Feminist Reader (New York: Blackwell, 2000); Lynn Chancer and Beverly Watkins, Gender, Race, and Class (New York: Blackwell Publishing, 2006); Elizabeth Fox-Genovese, Within the Plantation Household: Black and White Women of the Old South (Chapel Hill: University of North Carolina Press, 1988); Karen Rosenblum and Toni-Michelle C. Travis, Meaning of Difference: American Constructions of Race, Sex and Gender, Social Class, and Sexual Orientation (New York: Blackwell, 2005); Charisse Jones, Kumea Shorter-Gooden, Shifting: The Double Lives of Black Women in America (New York: HarperCollins, 2003); and Angela Y. Davis, Women, Race, and Class (New York: Vintage, 1983).

${ }^{7}$ See page 38 of Pero Gaglo Dagbovie, "Black Women, Carter G. Woodson, and the Association for the Study of Negro Life and History, 1915-1950," The Journal of African American History 88, no. 1 (2003): 21-41. See also Patricia Morton, Disfigured Images: The Historical Assault on Afro-American Women (Westport, CT: Greenwood, 1991); Deborah Gray White, Too Heavy a Load: Black Women in Defense of Themselves, 1894-1994 (New York: Norton, 1999); Bettina Aptheker, Woman's Legacy: Essays on Race, Sex, and Class in American History (Amherst, MA: University of Massachusetts Press, 1982); and Jean Fagan Yellin, "Du Bois Crisis and Woman's Suffrage," The Massachusetts Review 14 (Spring 1973), 365-75. For an interesting discussion of gender among African American historians, see Pero Gaglo Dagbovie, "Black Women Historians From the Late 19th Century to the Dawning of the Civil Rights Movement," The Journal of African American History 89, no. 3 (2004), 241-61. 


\section{Gasman}

${ }^{8}$ Please note that there are several books that pertain to black colleges, although not the history of these institutions, which may be helpful to readers. These include John Irving, Negro Students and Their Colleges (Boston: Meador, 1949); Frank Bowles and Frank A DeCosta, eds., Between Two Worlds: A Profile of Negro Higher Education (New York: McGraw-Hill, 1971); Arthur L. Klein, Survey of Negro Colleges and Universities (New York: Negro Universities Press, 1969); Abram J. Jaffe, Walter Adams, and Sandra G. Meyers, Negro Higher Education in the 1960's (Westport, CT: Praeger, 1968); Earl J. McGrath, The Predominantly Negro Colleges and Universities in Transition (New York: Teachers College, Columbia University, 1965); M. Christopher Brown and Kassie Freeman, Black Colleges: New Perspectives on Policy and Practice (Westport, CT: Praeger, 2004); Charles V. Willie, Richard J. Reddick, and Roland Brown, The Black College Mystique (Lanham, MD: Rowman \& Littlefield, 2006); Charles V. Willie and Ronald R. Edmonds, eds., Black Colleges in American: Challenge Development, and Survival (New York: Teachers College Press, 1978); and Patricia Gurin and Edgar Epps, Black Consciousness, Identity, and Achievement: A Study of Students in Historically Black Colleges (New York: John Wiley, 1975).

${ }^{9}$ This sweeping also took place in white feminist literature, which ignored the plight of African American women. For a thorough discussion, see bell hooks, Feminist Theory: From Margin to Center (Boston: South End, 2000); bell hooks, Ain't I A Woman; and V. P. Franklin, "Hidden in Plain View: African American Women, Radical Feminism, and the Origins of Women's Studies Programs, 1967-1974," The Journal of African American History 87 (Autumn 2002): 433-45.

${ }^{10}$ See The Traditionally Black Institutions of Higher Education, 1860-1982 (Washington, DC: National Center for Educational Statistics, 1983); and Thurgood Marshall Fund and Shirley M. Geiger, Understanding Gender at Public Historically Black Colleges and Universities (Washington, DC: Thurgood Marshall Fund, 2007).

${ }^{11}$ Bonner, "Addressing Gender Issues in the Historically Black College and University Community," 180-1. Frances Beale says this more bluntly in her chapter titled "Double Jeopardy: To Be Black and Female," in Beverly Guy-Sheftal's Words of Fire: "In keeping with its goal of destroying the black race's will to resist its subjugation, capitalism found it necessary to create a situation where the black man found it impossible to find meaningful or productive employment. More often than not, he couldn't find work of any kind. And the black woman likewise was manipulated by the system, economically exploited, and physically assaulted. She could often find work in the white man's kitchen, however, and sometimes became the sole breadwinner of the family. This predicament has led to many psychological problems on the part of both man and woman and has contributed to the turmoil that we find in the black family structure" (p. 146).

${ }^{12}$ Yolanda Watson and Sheila T. Gregory, Daring to Educate: The Legacy of Early Spelman College Presidents (Sterling, Virginia: Stylus, 2005).

${ }^{13}$ Ronald E. Butchart, "'Outthinking and Outflanking the Owners of the World': A Historiography of the African American Struggle for Education," History of Education Quarterly 28, no. 3 (1998): 333-66, 361. Butchart also wrote Northern Schools, Southern Blacks, and Reconstruction: Freedmen's Education, 1862-1875 (Westport, CT: Greenwood, 1980). In this book, he critiqued the efforts of both the Freedman's Bureau and the early missionary associations to provide education, mainly primary and secondary, to the freedmen. Butchart labeled the education provided "utterly inappropriate" (p. 9). Although he occasionally discusses the black teachers and students, there is little attention paid to black women.

${ }^{14}$ Alicia C. Collins, "Black Women in the Academy: An Historical Overview," in Reitumetse Obakeng Mabokela and Anna L. Green, eds., Sisters of the Academy: Emergent Black Women Scholars in Higher Education (Sterling, VA: Stylus, 2001), 2. See also Alicia C. Collins, "Socialization at Two Black Women's Colleges: Bennett College and Spelman College" (EdD diss., University of Pittsburgh, 2001).

${ }^{15}$ Glenn, "The Social Construction and Institutionalization of Gender and Race," 9.

${ }^{16}$ Ibid.

${ }^{17} \mathrm{Ibid}$.

${ }^{18}$ I modeled my approach to this historiography on the work of historian Ronald Butchart. See Butchart, "Outthinking and Outflanking the Owners of the World." Two other historiographies were helpful as well: Kathleen Weiler, "The History of Gender and 
Progressive Education in the United States," Paedagogica Historica 42, nos. 1-2 (2006): 161-76; and Jana Nidiffer, "Poor Historiography: The 'Poorest' in American Higher Education," History of Education Quarterly 39, no. 3 (1999): 321-36. See also, Aviezar Tucker, Our Knowledge of the Past: A Philosophy of Historiography (New York: Cambridge University Press, 2004). Also, it should be noted that although I read dissertations on the history of black colleges, I have not included a review of them in this article due to issues of length. These dissertations vary in quality and, by and large, unless specifically about women or gender issues, they do not address gender issues in any significant manner when examining the history of black colleges. The dissertations that I reviewed for this article and in my previous scholarship include $\mathrm{H}$. Randall Poole, "From Black to White: The Transition of Bluefield State College from an Historically Black College to a Predominantly White Institution" (PhD diss., University of Maryland, 1989); R. Thomas Garrett, "A Study of the Transition of Bluefield State College From a Black Teacher Preparation College to a Predominantly White Liberal Arts College" (EdD diss., Rutgers, the State University of New Jersey, 1989); Lamoyne Matthews, "Portrait of a Dean: A Biography of Inabel Burns Lindsay, First Dean of the Howard School of Social Work" (PhD diss., University of Maryland, 1976); Jerrold Wimbish, "Student Activism and the Historically Black University: Hampton Institute and Howard University, 1960-1972" (EdD diss., Harvard University, 2000); Zachery Williams, "In Search of the Talented Tenth: Howard University Intellectuals and the Dilemmas of Race in Academia, 1926-1970" (PhD diss, Bowling Green State University, 2003); Frances Thurman, "The History of Saint Paul's College, Lawrenceville, Virginia, 1888-1959" (PhD diss., Howard University, 1978); Cecil Taliaferro, "Virginia Union University, The First One Hundred Years, 1865-1965" (PhD diss., University of Pittsburgh, 1975); De Lois Gibson, "A Historical Study of Philander Smith College, 1877-1969" (EdD diss., University of Arkansas, 1972); Berkley Ramsey, "The Public Black College in Georgia: A History of Albany State College, 1903-1965" (PhD diss., Florida State University, 1973); Norman Rothman, "Curriculum Formation in a Black College: A Study of Morris Brown College, 1881-1980" (PhD diss., Georgia State University, 1981); George Clary, "The Founding of Paine College: A Unique Venture in Inter-racial Cooperation in the New South, 1882-1903" (EdD diss., University of Georgia, 1965); Alandus Johnson, "The Growth of Paine College: A Successful Interracial Venture" (PhD diss., University of Georgia, 1970); Terry Foster, "A Historical Examination of the Changing Mission of Kentucky State University" (EdD diss., Indiana University, 1992); Jimmy McJamerson, "Grambling State University: The Spirit, the History, and the Legacy through the Experience of Pioneers and Builders" (PhD diss., Union Institute and University, 2005); Mildred Gallot, "Grambling State University: A History, 1901-1977" (EdD diss., Louisiana State University and Agricultural and Mechanical College, 1982); Gretchen Jackson, "A Historical Analysis of the Development of Southern University and Its Teacher Education Program" (EdD diss., University of Houston, 2005); Valera T. Francis, "Pride and Paradox: The History and Development of Southern University at New Orleans, 1954-1975" (PhD diss., University of New Orleans, 2004); Cynthia Chapel, "Shifting History, Shifting Mission, Shifting Identity: The Search for Survival at Lincoln University (Jefferson City, Missouri), 1866-1997" (EdD diss., Oklahoma State University, 1997); Leonard Bethel, "The Role of Lincoln University (PA) in the Education of African Leadership, 1854-1970" (EdD diss., Rutgers, the State University of New Jersey, 1975); Lenwood Davis, "A History of Livingstone College, 1879-1957" (PhD diss., Carnegie Mellon University, 1979); Clara Jenkins, "An Historical Study of Shaw University, 1865-1963" (EdD diss., University of Pittsburgh, 1965); Frederick McGinnis, "A History of Wilberforce University" (PhD diss., University of Cincinnati, 1940); Frederick Richardson, "A Power for Good in Society: The History of Benedict College" (PhD diss., Florida State University, 1973); Charlestine Romelle, "A History of Claflin College, 1869-1987" (PhD diss., University of South Carolina, 1990); Albert Jabs, "The Mission of Voorhees College: Its Roots and Its Future" (EdD diss., University of South Carolina, 1983); Evelyn Fancher, "Tennessee State University (1912-1974): A History of an Institution with Applications for the Future" (PhD diss., Peabody College for Teachers of Vanderbilt University, 1975); Korang-Arthur Kobena, "The History of Paul Quinn College: Austin and Waco Years" (PhD diss., University of North Texas, 1992); Cassandra Evans-Herring, "An Intersectional Analysis of the Life Experiences of Mary Elizabeth Branch, the First Female Senior College 


\section{Gasman}

President" (PhD diss., Georgia State University, 2003); Barbara Isaacs, "The Lunch Counter Struggle, 1960-1963: Women Re-mapping Boundaries of Race, Gender, and Vocation" (PhD diss., Northwestern University, 2002); Yolanda Watson-Moore, "Training the Head, the Hand, and the Heart: The Evolution of the Academic Curriculum of Spelman College, 1881-1953" (PhD diss., Georgia State University, 2000); Nadine Lockwood, "Bennett College for Women, 1926-1966" (PhD diss., State University of New York at Buffalo, 2004); Vida Avery, "A Fateful Hour in Black Higher Education: The Creation of the Atlanta University System" (PhD diss., Georgia State University, 2003); Frances Graham, "The Founding of an All Black Female Seminary: Spelman, 1881-1927" (PhD diss., University of Illinois at Urbana-Champaign, 1996); Janice Leone, "The Mission of Women's Colleges in an Era of Cultural Revolution, 1890-1930" (PhD diss., Ohio State University, 1989); Karen Vanlandingham, "In Pursuit of a Changing Dream: Spelman College Students and the Civil Rights Movement, 1955-1962" (master's thesis, Emory University, 1985); Ishmell Edwards, "History of Rust College, 1866-1967" (PhD diss., University of Mississippi, 1993); Gail Cash, "Women at Hampton, 1930-1959" (PhD diss., Marquette University, 1994); Joseph McMillian, "The Development of Higher Education for Blacks During the Late Nineteenth Century: A Study of the African American Methodist Episcopal Church, Wilberforce University, The American Missionary Association, Hampton Institute, and Fisk University" (EdD diss., Columbia University, Teachers College, 1986); Katrina Sanders, "Building Racial Tolerance through Education: The Fisk University Race Relations Institute, 1944-1969" (PhD diss., University of Illinois at Urbana-Champaign, 1997); Madhavi Venkatesan, "Black Higher Education and the American Labor Market: A Century at Fisk University" (PhD diss., Vanderbilt University, 1996); Clifford Muse, "An Educational Stepchild: Howard University during the New Deal, 1933-1945" (PhD diss., Howard University, 1989); Chonita Robinson Spencer, "A Study of the Contributions of Stephen J. Wright, An American Education" (EdD diss., Rutgers, the State University of New Jersey, 1988); Harry Beamon, "The Rise and Demise of Physical Education at Fisk University: A Historical Analysis" (EdD diss., Peabody College for Teachers of Vanderbilt University, 1979); Earl Wright, "Atlanta University and American Sociology, 1896-1917: An Earnest Desire for the Truth Despite Its Possible Unpleasantness" (PhD diss., University of Nebraska, 2000); Leroy Davis, "John Hope of Atlanta: Race Leader and Black Educator" (PhD diss., Kent State University, 1989); Wilma Hunter, "Coming of Age: Hollis B. Frissell and the Emergence of Hampton Institute, 1893-1917" (PhD diss., Indiana University, 1982); William Robinson, "The History of Hampton Institute, 1868-1949" (PhD diss., New York University, 1954); Keith Barry, "Charles S. Johnson, Fisk University, and the Struggle for Civil Rights, 1945-1970" (PhD diss., Florida State University, 2005); Shawn Comminey, "A History of Straight College, 1869-1935" (PhD diss., Florida State University, 2003); Marybeth Gasman, “A Renaissance in Nashville: Charles S. Johnson's Use of Philanthropy to Build Fisk University in the Post-War Period" (PhD diss., Indiana University, 2000); Florence Roane, "A Cultural History of Professional Teacher Preparation at BethuneCookman College" (EdD diss., Boston University, 1965); Dereck Rovaris, "Developer of an Institution: Dr. Benjamin E. Mays, Morehouse College President, 1940-1967" (PhD diss., University of Illinois at Urbana-Champaign, 1990); Jelani Favors, "Shelter in a Time of Storm: Black Colleges and the Rise of Student Activism in Jackson, Mississippi" (PhD diss., Ohio State University, Columbus, 2006); Clarice Campbell, "A History of Tougaloo College" (PhD diss., University of Mississippi, 1970); Alicia C. Collins, "Socialization at Two Black Women's Colleges: Bennett College and Spelman College" (EdD diss., University of Pittsburgh, 2001); Karen Ann Johnson, "Uplifting the Women and the Race: A Black Feminist Theoretical Critique of the Lives, Works and the Educational Philosophies of Anna Julia Cooper and Nannie Helen Burroughs" (PhD diss., University of California, Los Angeles, 1997); Christiane Warren-Christian, "Anna Julia Cooper: Feminist and Scholar" (PhD diss., Drew University, 2003); Eva Semien Baham, "Anna Julia Haywood Cooper, A Stream Cannot Rise Higher Than Its Source: The Vanguard as the Panacea for the Plight of Black America" (PhD diss., Purdue University, 1997); Jacqueline Young, "A Study of the Education Philosophies of Three Pioneer Black Women and Their Contributions to American Education (Coppin, Bethune, and Brown)" (EdD diss., Rutgers, the State University of New Jersey, 1987), Barbara Blackwell, "The Advocacies and Ideological Commitments of a Black Educator: Mary McLeod Bethune, 1875-1955" (PhD diss., 
University of Connecticut, 1979); Audrey T. McCluskey, "Mary McLeod Bethune and the Education of Black Girls in the South, 1904-1923" (PhD diss., Indiana University, 1991); and Stephanie Evans, "Living Legacies: Black Women, Educational Philosophies, and Community Service, 1865-1965" (PhD diss., University of Massachusetts, Amherst, 2003).

${ }^{19}$ Patrick J. Gilpin and Marybeth Gasman, Charles Spurgeon Johnson: Leadership behind the Veil in the Age of Jim Crow (Albany: State University of New York Press, 2003).

${ }^{20}$ Marybeth Gasman, Envisioning Black Colleges: A History of the United Negro College Fund (Baltimore, MD: Johns Hopkins University Press, 2007).

${ }^{21}$ Johnetta Cross Brazzell, "Bricks without Straw: Missionary-Sponsored Black Higher Education in the Post-Emancipation Era," The Journal of Higher Education 63, no. 1 (1992): 26-49.

${ }^{22}$ Collins, "Black Women in the Academy."

${ }^{23}$ William T. Alexander, History of the Colored Race in America (New York: Negro Universities Press, 1887); and Constance Carroll, "Three's a Crowd: The Dilemma of the Black Woman in Higher Education," in Gloria Hull, Patricia Bell-Scott, and Barbara Smith, eds., But Some of Us Are Brave: Black Women's Studies (New York: Feminist Press, 1982), $115-28$.

${ }^{24}$ Marybeth Gasman and Katherine V. Sedgwick, eds., Uplifting a People: African American Philanthropy and Education (New York: Peter Lang, 2005); Collins, "Black Women in the Academy"; and Brazzell, "Bricks without Straw."

${ }^{25}$ W. E. B. DuBois, "Of the Training of Black Men," Atlantic Monthly 90 (1902): 289-97.

${ }^{26}$ Patricia Coleman-Burns, "African American Women: Education for What?" Sex Roles 21, nos. 1-2 (1989): 145-60. See also Lucy Diggs Slowe, "Higher Education of Negro Women," The Journal of Negro Education 2, no. 3 (1933): 352-8.

${ }^{27}$ Although not discussed here, the reader should see, Kelly Miller, "The Past, Present and Future of the Negro College," The Journal of Negro Education 2, no. 3 (1933), 411-22. Interestingly, Miller's history does not mention women or gender relations once in the article.

${ }^{28}$ Carter G. Woodson, The Education of the Negro Prior to 1861: A History of the Education of the Colored People of the United States from the Beginning of Slavery to the Civil War (New York: Kessinger, 1919). It should be noted that issues of gender were not interrogated in any substantial way during this time by historians and as such, criticism of this early work on the history of black colleges should be read with this in mind. Regardless, I think it is important to include these early histories, especially as they were written by luminaries in the field such as Woodson.

${ }^{29}$ Linda M. Perkins, Fanny Jackson Coppin and the Institute for Colored Youth, 1865-1902 (New York: Garland, 1987). Perkins discusses the Institute for Colored Youth (which would become Cheyney University). However, Perkins's discussion focuses on the institute only and the primary and secondary education offered by it.

${ }^{30}$ Carter G. Woodson, The Mis-Education of the Negro (New York: Associated Publishers, 1933), 30 .

${ }^{31}$ Glenn, "The Social Construction and Institutionalization of Gender and Race."

${ }^{32}$ Woodson, The Mis-Education of the Negro, 128.

${ }^{33}$ For a thorough discussion, see Paula Giddings, When and Where I Enter: The Impact of Black Women on Race and Sex in America (New York: Quill William Morrow, 1984).

${ }^{34}$ Woodson, The Mis-Education of the Negro, 128.

${ }^{35}$ Dwight O. W. Holmes, "The Beginnings of the Negro College," The Journal of Negro Education 3, no. 2 (1934): 168-93; Dwight O. W. Holmes, "Seventy Years of the Negro College 1860 to 1930," Phylon 10, no. 4 (1949): 307-13; and Dwight O. W. Holmes, Evolution of the Negro College (New York: Ayer Company, 1969). A book worth reviewing from this time period is Theophilus McKinney's Higher Education among Negroes (Charlotte, NC: Johnson C. Smith University, 1932).

${ }^{36}$ Holmes, "The Beginnings of the Negro College," 188.

${ }^{37}$ Horace Mann Bond, The Education of the Negro in the American Social Order (New York: Octagon Books, 1966); Horace Mann Bond, "The Origin and Development of the Negro Church-Related College," The Journal of Negro Education 29, no. 3 (1960): 217-26; and Horace Mann Bond, "The Evolution and Present Status of Negro Higher and Professional Education in the United States," The Journal of Negro Education (Summer 1948): 224-35 (here, Bond discusses the racial makeup of black colleges). 


\section{Gasman}

${ }^{38}$ Bond, The Education of the Negro in the American Social Order, 360.

${ }^{39}$ Henry Allen Bullock, A History of Negro Education in the South from 1619 to the Present (Cambridge, MA: Harvard University Press, 1967).

${ }^{40}$ Stephen J. Peeps, "Northern Philanthropy and the Emergence of Black Higher Education: Do Gooders, Compromisers, or Co-conspirators?" The Journal of Negro Education 50, no. 3 (1981): 251-69.

${ }^{41}$ Ibid., 252.

${ }^{4}$ Ibid.

${ }^{43}$ James D. Anderson, The Education of Blacks in the South, 1860-1935 (Chapel Hill: University of North Carolina Press, 1988).

${ }^{4}$ Ibid., 17.

${ }^{45}$ Robert Engs, Educating the Disenfranchised and Disinherited: Samuel Chapman Armstrong and the Hampton Institute, 1839-1893 (Knoxville: University of Tennessee, 1999). Please note that many of the early leaders of black colleges were referred to as principals rather than presidents due to the type of curriculum being offered.

${ }^{46}$ See Anderson, The Education of Blacks in the South. For the specific passage on gender, see pages 55 and 56. Anderson also includes several photos of black womensewing and cooking at Hampton Institute and in a domestic science class at South Carolina State University.

${ }^{47}$ Brazzell, "Bricks without Straw." For another discussion of missionary philanthropy, albeit based on secondary sources, see Jane E. Smith Browning and John B. Williams, "History and Goals of Black Institutions of Higher Learning," in Black Colleges in America: Challenge, Development, and Survival, ed. Charles V. Willie and Ronald R. Edmonds (New York: Teachers College Press, 1978), 68-96.

${ }^{48}$ Thomas Woody, A History of Women's Education in the United States (New York: Octagon Books, 1929).

${ }^{49}$ Brazzell, "Bricks without Straw," 36.

${ }^{50}$ Ibid., 46.

${ }^{51}$ Eric Anderson and Alfred Moss, Dangerous Donations: Northern Philanthropy and Southern Black Education, 1902-1930 (Columbia: University of Missouri Press, 1999).

${ }^{52}$ For the discussion of Anna T. Jeanes, please see page 82 of Anderson and Moss, Dangerous Donations. It should be noted that James D. Anderson, The Education of Blacks in the South, 1860-1935, also includes some information on the Anna T. Jeanes Fund. See also Michael Fultz, "Teacher Training and African American Education in the South, 1900-1940," The Journal of Negro Education 64, no. 2 (1995): 196-210.

${ }^{5}$ Anderson and Moss, Dangerous Donations, 21.

${ }^{5}$ Ibid., 25.

${ }^{55}$ Although not a history of black colleges specifically, Adam Fairclough's 2000 article is noteworthy. Fairclough examines black teachers at mostly the primary and secondary level but does include some discussion of teachers in early black colleges. Overall, his emphasis is on black male teachers; he notes their political involvement (once they gained the right to vote) and their influence in the black community. In the only example of depth with regard to black women, Fairclough discusses the "bowing and scraping" that black female teachers often had to do in front of their white superintendents. Fairclough credits the women's intellect, noting their awareness of how "acting proper" would secure for them "books, equipment, playgrounds, and better wages" (p. 80). See Adam Fairclough, "Being in the Field of Education and also Being a Negro ... Seems . . . Tragic": Black Teachers in the Jim Crow South," The Journal of American History 87, no. 1 (2000): 65-91.

${ }^{56}$ William Watkins, White Architects of Black Education: Ideology and Power in America, 1865-1954 (New York: Teachers College Press, 2001).

${ }^{57}$ Franklin, "Hidden in Plain View."

${ }^{58}$ Daniel C. Thompson, Private Black Colleges at the Crossroads (Westport, CT: Greenwood, 1973), 49.

${ }^{59}$ Jean Carey Bond and Patricia Perry, "Is the Black Male Castrated?" in The Black Woman, ed. Toni Cade Bambara (New York: Signet, 1970), 114-5. I located this source in Cole and Guy-Sheftal's Gender Talk. Emphasis in quotation added by author.

${ }^{60}$ Daniel Patrick Moynihan, The Negro Family: The Case for National Action (Washington, D.C.: Department of Labor, 1965); and E. Franklin Frazier's Negro Family in 
the United States (New York: Dryden, 1951).

${ }^{61}$ Thompson, Private Black Colleges, 123.

${ }^{6}$ Michael B. Katz, Mark J. Stern, and Jamie J. Fader, "Women and the Paradox of Economic Inequality in the Twentieth-Century," Journal of Social History 39, no. 1 (2005): 65-88.

${ }^{6}$ Thompson, Private Black Colleges, 124.

${ }^{6}$ Ibid., 123.

${ }^{65}$ Ibid., 124 .

${ }^{6}$ Ibid.

${ }^{67}$ Ibid., 125.

${ }^{68}$ Linda M. Perkins, "For the Good of the Race: Married African-American AcademicsA Historical Perspective," in Marianne A. Ferber and Jane W. Loeb, Academic Couples: Problems and Promises (Urbana and Chicago: University of Illinois Press, 1997), 80-105.

${ }^{6}$ Ibid., 103. It is interesting to note that this chapter (chap. 3) is located in a book having little to do with the history of black colleges. Even someone steeped in the literature on the history of black colleges would likely miss it when searching for secondary sources.

${ }^{7}$ Ibid., 224.

${ }^{71}$ Ibid., 234.

${ }^{72}$ Linda Beatrice Brown, The Long Walk: The Story of the Presidency of Willa B. Player at Bennett College (Greensboro, NC: Bennett College Leadership Institute, 1998).

${ }^{73}$ Isaac H. Miller was president of Bennett College in 1973.

${ }^{74}$ White women's colleges faced the same challenges to justify the need for separate education.

${ }^{75}$ Watson and Gregory, Daring to Educate. See also Beverly Guy-Sheftal and Jo Moore Stewart, eds., Spelman: A Centennial Celebration (Atlanta, GA: Spelman College, 1981).

${ }^{76}$ Patricia Bell-Scott, "Schoolin' 'Respectable' Ladies of Color: Issues in the History of Black Women's Higher Education," Journal of NAWDAC 43, no. 2 (1980): 22-28.

${ }^{77}$ For a brief discussion of the black female presidents after the publication of Thompson's book, see Mary Frances Berry, "Twentieth-Century Black Women in Education," The Journal of Negro Education 51, no. 3 (1982), 288-300.

${ }^{78}$ Raymond Wolters, The New Negro on Campus: Black College Rebellions of the 1920 s (Princeton, NJ: Princeton University Press, 1975).

${ }^{79}$ Henry Drewry and Humphrey Doermann, Stand and Prosper: Private Black Colleges and Their Students (Princeton, NJ: Princeton University Press, 2001), 34-36.

${ }^{80}$ Ibid., 55. For a more detailed discussion of black missionary teachers, see Brazzell, "Bricks without Straw." Also, in Anderson and Moss's Dangerous Donations, the authors discuss Charlotte Forten's work in primary and secondary schools and how she inculcated students with a sense of racial pride through her teaching. She used the "Haitian insurrectionist Toussanit L'Ouverture and other blacks who resisted enslavement as historical models for her students." (p. 24). Forten seems to be one of the few black women worth mentioning in the history of black education. She is also mentioned, although briefly, in Rayford Logan, "The Evolution of Private Colleges for Negroes," The Journal of Negro Education 27, no. 3 (1958): 213-20.

${ }^{81}$ For more information on Anna Julia Cooper and Charlotte Hawkins Brown, see F. R. Keller, "An Educational Controversy: Anna Julia Cooper's Vision of Resolution," National Women's Studies Association Journal 11, no. 3 (1999): 49-67; Charles Weldon Wadelington and Richard Knapp, Charlotte Hawkins Brown and Palmer Memorial Institute: What One Young African American Woman Could Do (Chapel Hill: University of North Carolina Press, 1999); C. Lemert and E. Bhan, eds., The Voice of Anna Julia Cooper: Including A Voice from the South and Other Important Essays, Papers, and Letters (Lanham, MD: Rowman \& Littlefield, 1998); E. Alexander, "We Must Be about Our Father's Business': Anna Julia Cooper and the Incorporation of the Nineteenth-Century African American Women Intellectual," Signs: Journal of Women in Culture and Society 20, no. 2 (1995), 336-56; Elizabeth. L. Ihle, Black Women in Higher Education: An Anthology of Essays, Studies, and Documents (New York: Garland, 1992); L. Henry, "Promoting Historical Consciousness: The Early Archives Committee of the National Council of Negro Women," Signs: Journal of Women in Culture and Society 7, no. 1 (1981): 251-9; Warren- 


\section{Gasman}

Christian, "Anna Julia Cooper: Feminist and Scholar"; Baham, "Anna Julia Haywood Cooper, A Stream Cannot Rise Higher Than Its Source"; and Johnson, "Uplifting the Women and the Race."

${ }^{82}$ Linda M. Perkins, "Lucy Diggs Slowe: Champion of the Self-Determination of African American Women in Higher Education," The Journal of Negro History 81, nos. 1-4 (1996): 89-104; Patricia Bell-Scott, "To Keep My Self-Respect: Dean Lucy Diggs Slowe's 1927 Memorandum on the Sexual Harassment of Black Women," National Women's Studies Association Journal 9 (1997): 70-76. For more information on Lucy Diggs Slowe, see K. Anderson, "Brickbats and Roses: Lucy Diggs Slowe, 1883-1937," in Lone Voyagers: Academic Women in Coeducational Institutions, 1870-1937, ed. G. Clifford (New York: Feminist Press, 1989), 283-307; Lucy Diggs Slowe, "A Colored Girl Enters College: What Shall She Expect?" Opportunity (September, 1937): 276; and National Association of College Women, "Memorial Tributes to Lucy Slowe," National Association of College Women Journal 14 (1937): 49-51.

${ }^{83}$ Bell-Scott, "To Keep My Self-Respect."

${ }^{84}$ See Lucy Diggs Slowe, "Higher Education for Negro Women," The Journal of Negro Education 2, no. 3 (1933): 352-58, 355.

${ }^{85}$ Jana Nidiffer, Pioneering Deans: More Than Wise and Pious Matrons (New York: Teachers College Press, 1999); and Linda Eisenmann, "Creating a Framework for Interpreting U.S. Women's Educational History: Lessons from Historical Lexicography," History of Education 30, no. 5 (2001): 453-70.

${ }^{86}$ Mills in Bell-Scott, "To Keep My Self-Respect," 72.

${ }^{87}$ For more information on Howard University and Mordecai Johnson, see Walter Dyson, Howard University: The Capstone of Negro Education. A History, 1897-1940 (Washington, DC: Graduate School at Howard University, 1941). Please note that this is a "house history" and refrains from applying any significant criticism to the leadership of the institution.

${ }^{88}$ Richard I. McKinny, Mordecai, the Man and His Message: The Story of Mordecai Wyatt Johnson (Washington, DC: Howard University Press, 1998); and Perkins, "Lucy Diggs Slowe."

${ }^{89}$ Bell-Scott, "To Keep My Self-Respect," 74. Original document can be found in the Moorland-Spingarn Research Center, Howard University, Washington, D.C.

${ }^{90}$ Rayford Logan, Howard University: The First Hundred Years, 1867-1977 (New

York: New York University Press, 1979).

${ }^{91}$ Ibid., PLS PROVIDE PAGE NO. FOR DIRECT QUOTE.

${ }_{92}$ See Guy-Sheftal's Words of Fire.

${ }^{93}$ For an example, see Christopher Jencks and David Riesman, "The American Negro College," Harvard Educational Review 37, no. 2 (1967): 3-60. And for discussion of white outsider research and black colleges, see Marybeth Gasman, "Salvaging 'Academic Disaster Areas': The Black College Response to Christopher Jencks' and David Riesman's 1967 Harvard Educational Review Article," Journal of Higher Education 77, no. 2 (2006): 317-52.

${ }^{94}$ Patricia Bell-Scott, "The Business of Being Dean of Women: A Letter from Lucy Diggs Slowe to Howard University Board of Trustees," Initiatives: The Journal of the National Association of Women's Education (n.d.). See Guy-Sheftal's Words of Fire. It should be noted that many white male presidents had reputations for being autocratic but tend to be lauded in the historical literature for their "strong leadership." For a fascinating discussion of the uneven treatment of black and white college presidents in historical literature, see Philo A. Hutcheson, "Shall I Compare Thee? Reflections on Naming and Power," in Understanding Minority Serving Institutions, ed. Marybeth Gasman, Benjamin Baez, and Caroline Sotello Turner (New York: State University of New York Press, forthcoming).

${ }^{95}$ For a detailed discussion of black women and their role in the civil rights movement, please see Giddings, When and Where I Enter.

${ }_{97}^{6}$ Cole and Guy-Sheftal, Gender Talk, 90.

${ }^{97}$ See Harry G. Lefhever, Undaunted by the Fight: Spelman College and the Civil Rights Movement, 1957-1967 (Macon, GA: Mercer University Press, 2005); and G. O'Brien, "Five Campuses Hit by Protest," The Chronicle of Higher Education, May 3, 1976, 4.

${ }^{98}$ Gasman, Envisioning Black Colleges; See also Joy A. Williamson, "'This Has Been Quite a Year for Heads Falling': Institutional Autonomy in the Civil Rights Era," History of Education Quarterly 44, no. 4 (2004): 489-511. 
${ }^{99}$ Willa Player, "Report to the Executive Committee of the Board of Trustees," Bennett College Archives, Greensboro, North Carolina (1960), 21. For a detailed discussion of this report, see Brown, The Long Walk.

${ }^{100}$ Williamson, "This Has Been Quite a Year for Heads Falling."

${ }^{101}$ For a discussion of the often overlooked role of women in the civil rights movement, see Franklin, "Hidden in Plain View."

${ }^{102}$ Gasman, Envisioning Black Colleges; see also Bettye-Collier Thomas and V. P. Franklin, eds., Sisters in the Struggle: African American Women in the Civil Rights and Black Power Movements (New York: New York University Press, 2001); Bettye CollierThomas, "The Impact of Black Women in Education: An Historical Overview," Journal of Negro Education 51 (Summer 1982): 254-65; Vicki Crawford, Jacqueline Rouse, and Barbara Woods, eds., Women in the Civil Rights Movement: Trailblazer and Torchbearers, 1941-1965 (Bloomington: Indiana University Press, 1993); and Higginbotham, Too Much to Ask.

${ }^{103}$ Bell-Scott, "Schoolin' 'Respectable' Ladies of Color." For a description of the art of living, see Brown, The Long Walk.

${ }^{104}$ Interestingly, the Ford Foundation had a rocky past with black colleges, calling for their closure during the decade after Brown v. Board and refusing to support the United Negro College Fund because it thought the organization perpetuated segregation. For a thorough discussion of this relationship, see Gasman, Envisioning Black Colleges.

103 Drewry and Doermann, Stand and Prosper.

${ }^{106}$ Juan Williams and Dwayne Ashley, "I'll Find a Way or Make One": A Tribute to Historically Black Colleges and Universities (New York: Amistad Books, 2004).

${ }^{107}$ For a more in-depth discussion of the African American sororities, see Paula Giddings, In Search of Sisterhood: Delta Sigma Theta and the Challenge of the Black Sorority Movement (New York: Amistad Books, 1994); and Marjorie Parker, Past is Prologue: The History of Alpha Kappa Alpha 1908-1999 (Washington, DC: Alpha Kappa Alpha, 1999).

${ }^{108}$ Bethune is covered extensively in general history literature. See Audrey McCluskey and Elaine M. Smith, eds., Mary McLeod Bethune (Bloomington: Indiana University Press, 2002); Joyce A. Hansen, Mary McLeod Bethune and Black Women's Political Activism (Columbia: University of Missouri Press, 2003); Audrey T. McCluskey, "Representing the Race: Mary McLeod Bethune and the Press in the Jim Crow Era," Western Journal of Black Studies 23, no. 4 (1999): 236-45; C. Linsin, "Something More than a Creed: Mary McLeod Bethune's Aim of Integrated Autonomy as Director of Negro Affairs," Florida Historical Quarterly 76, no. 1 (1997): 20-41; Audrey T. McCluskey, "We Specialize in the Wholly Impossible: Black Women School Founders and Their Mission," Signs: Journal of Women in Culture and Society 22, no. 2 (1997): 403-26; Elaine Smith, "Mary McLeod Bethune's 'last will and testament': A Legacy for Race Vindication," The Journal of Negro History 81, nos. 1-4 (1996): 105-22; Audrey T. McCluskey, "Multiple Consciousness in the Leadership of Mary McLeod Bethune," National Women's Studies Association Journal 6, no. 1 (1994): 69-81; Audrey T. McCluskey, "Ringing up a School: Mary McLeod Bethune's Impact on Daytona," Florida Historical Quarterly 73, no. 2 (1994): 200-17; and B. J. Ross, "Mary McLeod Bethune and the National Youth Administration: A Case Study of Power Relationships in the Black Cabinet of Franklin D. Roosevelt," The Journal of Negro History 60, no. 1 (1975): 1-28. See also Linda Eisenmann, "Creating a Framework for Interpreting U.S. Women's Educational History: Lessons from Historical Lexicography"; Hansen, "The Ties that Bind"; Young, "A Study of the Education Philosophies of Three Pioneer Black Women"; Blackwell, "The Advocacies and Ideological Commitments of a Black Educator"; and McCluskey, "Mary McLeod Bethune and the Education of Black Girls in the South."

${ }^{109}$ Williams and Ashley, "I'll Find a Way or Make One," 96.

${ }^{110}$ Ibid.

${ }^{111}$ Although not discussed in this section, the reader might also find Susan Kates's "Elocution and African American Culture: The Pedagogy of Hallie Quinn Brown," in Susan Kates, Activist Rhetorics and American Higher Education (Carbondale and Edwardsville: Southern Illinois University Press, 2001), of interest. Kates discusses Hallie Quinn Brown, who was a professor of elocution at Wilberforce University from 1893 to 1923. This article briefly examines Brown's experiences at Wilberforce, but the main thrust is an examination of the pedagogical materials and elocutionary theory purported by Brown. 


\section{Gasman}

${ }_{112}^{11}$ Bell-Scott, "Schoolin' 'Respectable' Ladies of Color."

113 Ibid.

${ }^{114}$ Ibid. See also Slowe, "Higher Education of Negro Women," for a thorough discussion of the use of St. Paul's philosophies at black colleges.

115 Jeanne L. Noble, "Negro Women Today and Their Education," The Journal of Negro Education 26, no. 1 (1957): 15-21; and Jeanne Noble, The Negro Woman's College Education (New York: Columbia University Press, 1956). See also Patricia S. Stringer and Irene Thompson, Stepping off the Pedestal: Academic Women in the South (New York: Modern Language Association of America, 1982); and Marian Cuthbert, Education and Marginality: A Study of the Negro Woman College Graduate (New York: Garland, 1987).

116 Noble, The Negro Woman's College Education, 21.

${ }^{11}{ }^{7}$ Ibid., 17.

${ }_{118}^{1}$ Ibid., 24 .

${ }^{119}$ Guy-Sheftal, Words of Fire.

${ }^{120}$ Noble, The Negro Woman's College Education, 19.

${ }^{121}$ Bell-Scott, "Schoolin' 'Respectable' Ladies of Color."

${ }^{122}$ See page 23 of Bell-Scott, "Schoolin' 'Respectable' Ladies of Color."

${ }^{123}$ Virginia Ann Sutton, "The Early History of Bennett College." Self-published, Winston-Salem, NC, 1969; Walter Chivers, "The Founding of Spelman College: A Challenge to Negro Women," Spelman Messenger 59 (May 1943): 7-10; Oran Eagleston and Eleanor Bell, "The Values of Negro Women College Students," Journal of Social Psychology 22 (November 1945): 149-54; and Flemmie Kittrell, "Home Economics at Bennett College for Women," Southern Workman 60 (1931): 381-4.

${ }^{124}$ Bell-Scott, "'Schoolin' 'Respectable' Ladies of Color." See also M. Parsons, "Mount Holyoke of the South," Home Mission Monthly (1908); Florence Read, The Story of Spelman College (Princeton, NJ: Princeton University Press, 1961); and Florence Read, "The Place of Women's College in the Pattern of Negro Education," Opportunity 15 (1937): 267-70.

${ }^{125}$ See Rita Liberti, "Fostering Community Consciousness: The Role of Women's Basketball at Black Colleges and University, 1900-1950," in Race and Sport: The Struggle for Equality on and off the Field, ed. Charles K. Ross (Oxford: University of Mississippi Press, 2004), 40-58; Rita Liberti (1999) "We Were Ladies, We Just Played Like Boys': African American Womanhood and Competitive Basketball at Bennett College, 1928-1942," Journal of Sport History 26, no. 3: 567-84; Rita Liberti, "Exploring the Place and Significance of Physical Education at Black Colleges and Universities during the Late Nineteenth and Early Twentieth Centuries," Western College Physical Education Society Monograph Series (Washington State University at Pullman, 2000).

${ }^{126}$ Liberti, "We Were Ladies, We Just Played Like Boys"; and Liberti, "Exploring the Place and Significance," 572.

${ }^{127}$ Watson and Gregory, Daring to Educate. For a more extensive discussion of this idea, see Stephanie Shaw, What a Woman Ought to Be and Do: Black Professional Women and Workers during the Jim Crow Era (Chicago: University of Chicago Press, 1996), 50.

${ }^{128}$ Watson and Gregory rely on Perkins, "Lucy Diggs Slowe"; Linda M. Perkins, "The Racial Integration of the Seven Sisters," The Journal of Blacks in Higher Education 19 (Spring 1988): 104-8; and Linda M. Perkins, "Head Life's Demands': The Educational Philosophy of Fanny Jackson Coppin,” The Journal of Negro Education 51, no. 3 (1982): 181-90.

${ }^{129}$ See Collins, Black Feminist Thought; Sharon Harley, Sister Circle: Black Women and Work (Piscataway, NJ: Rutgers University Press, 2002); and Bonnie Thorton Dill and Bruce B. Williams, "Race, Gender, and Poverty in the Rural South: African American Single Mothers," in Rural Poverty in America, ed. Cynthia Duncan (New York: Auburn House, 1992), 97-110. According to Harley, Dill, and Williams, black women have historically been (and still are) more involved in the labor market and therefore more visible in "public" life than white women.

${ }^{130}$ Patricia Palmieri, "From Republican Motherhood" in The History of Higher Education, ed. Lester Goodchild (New York: Simon \& Schuster, 1997), 173-82; Linda M. Perkins, "Cult of True Womanhood" in The History of Higher Education, ed. Lester Goodchild (New York: Simon \& Schuster, 1997), 183-90; and Barbara Solomon, In the Company of Educated Women (New Haven, CT: Yale University Press, 1985). 
${ }^{131}$ Stephanie Y. Evans, Black Women in the Ivory Tower, 1850-1954 (Gainesville: University Press of Florida, 2007). See also Evans, "Living Legacies."

${ }^{132}$ Ihle, Black Women in Higher Education. For another source containing primary documents, see John Bracey, "Afro-American Women: A Brief Guide to Writings from Historical and Feminist Perspectives," Journal of Women's History 14 (Summer 2002): 140-3.

${ }_{133}$ Evans, Black Women in the Ivory Tower, 46.

${ }^{134}$ Ibid., 46.

135 Ibid., 111.

${ }^{136}$ Ibid.

${ }^{137}$ Noble, The Negro Woman's College Education, 15.

${ }^{138}$ See, for example, Darlene Clark Hine, ed., Black Women in America (New York: Oxford University Press, 2005); and Darlene Clark Hine and Kathleen Thompson, eds., $A$ Shining Thread of Hope: A History of Black Women in America (New York: Broadway Books, 1999); Lena Wright Myers, A Broken Silence: Voices of African American Women in the Academy (New York: Bergin \& Garvey, 2002); Cheryl Townsend Gilkes, If It Wasn't for the Women ... Black Women's Experience and Womanist Culture in Church and Community (New York: Orbis Books, 2000); and Kathleen Thompson and Hilary Mac Austin, eds., The Face of our Past: Images of Black Women from Colonial American to the Present (Bloomington: Indiana University Press, 2000).

${ }^{139}$ See, for example, Yolanda Moses, Black Women in Academe: Issues and Strategies. (Washington, DC: Association of American Colleges and Universities, 1989); and Myers, $A$ Broken Silence.

${ }^{140}$ See, for example, Frances D. Graham and Susan L. Poulson, "Spelman College: A Place All Their Own," in Challenged by Coeducation: Women's Colleges Since the 1960s, ed. Leslie Miller-Bernal and Susan L. Poulson (Nashville, TN: Vanderbilt University Press, 2006), 234-56.

${ }^{141}$ Alicia Boisnier, "Race and Women's Identity Development: Distinguishing Between Feminism and Womanism among Black and White Women," Sex Roles 49, nos. 5-6 (2003): 211-8.

${ }^{142}$ For one perspective, see Valora Washington and Joanna Newman, "Setting Our Own Agenda: Exploring the Meaning of Gender Disparities among Blacks in Higher Education," The Journal of Negro Education 60, no. 1 (1991): 19-35.

${ }^{143}$ With regard to African American women, see Darlene Clark Hine, Black Women in United States History: From Colonial Times to the Present (Brooklyn: Carlson, 1990); Darlene Clark Hine, Black Women and the Re-construction of American History. (Bloomington: Indiana University Press, 1994); Darlene Clark Hine, A Shining Thread of Hope: The History of Black Women in America (New York: Broadway Books, 1998); Darlene Clark Hine, Elsa Barkley Brown, and Rosalyn Terborg-Penn, eds., Black Women in America: An Historical Encyclopedia (Bloomington: Indiana University Press, 1994); Dorothy Sterling, We Are Your Sisters: Black Women in the Nineteenth Century (New York: Norton, 1997); and White, Too Heavy a Load.

${ }^{14}$ Elaine Seymour and Nancy Hewitt, Talking about Leaving: Why Undergraduates Leave the Sciences (Boulder, CO: Westview, 2000); and S. T. Hill and M. M. Green, Science and Engineering Degrees, by Race/Ethnicity of Recipients: 1995-2004 (Arlington, VA: National Science Foundation, 2007). For another interesting discussion of this idea, please see Shaun R. Harper, "High-Achieving African American Men's Behavioral Responses to Stereotypes at Predominantly White Universities." Paper presented at the annual meeting of the Association for the Study of Higher Education, Philadelphia, PA, November 17-19, 2005.

${ }^{145}$ Marybeth Gasman, Cynthia Gerstl-Pepin, Sibby Anderson-Thompkins, Lisa Rasheed, and Karry Hathaway, "Developing Trust, Negotiating Power: Transgressing Race and Status in the Academy," Teachers College Record 106, no. 4 (2004): 689-715; Anita Allen-Castellitto and Kevin Noble Maillard, "Student and Faculty Perspectives on Black Americans' Success in the White Academy," The Negro Educational Review 52, no. 3 (2001): 89-99; M. Christopher Brown, James L. Davis, and Shendrick .A. McClendon, "Mentoring Graduate Students of Color: Myths, Models, and Modes. Peabody Journal of Education 74, no. 2 (1999): 105-18; and Martin N. Davidson and Lynn Foster-Johnson, "Mentoring in the Preparation of Graduate Researchers of Color," Review of Educational Research 71, no. 4 (2001): 549-74. 


\section{Gasman}

${ }^{146}$ For a thorough discussion of this idea, see Kassie Freeman, African American Culture and Heritage in Higher Education Research and Practice (Westport, CT: Praeger, 1998).

\section{References}

Alexander, E. 1995. We must be about our father's business: Anna Julia Cooper and the incorporation of the nineteenth-century African American women intellectual. Signs: Journal of Women in Culture and Society, 20 (2): 336-56.

Alexander, William T. 1887. History of the Colored Race in America. New York: Negro Universities Press.

Allen-Castellitto, Anita, and Kevin Noble Maillard. 2001. Student and faculty perspectives on black Americans' success in the white academy. The Negro Educational Review, 52 (3): 89-99.

Anderson, Eric, and Alfred Moss. 1999. Dangerous donations: Northern philanthropy and Southern black education, 1902-1930. Columbia: University of Missouri Press.

Anderson, James D. 1988. The education of blacks in the South, 1860-1935. Chapel Hill: University of North Carolina Press.

Anderson, K. 1989. Brickbats and roses: Lucy Diggs Slowe, 1883-1937. In Lone voyagers: Academic women in coeducational institutions, 1870-1937, edited by G. Clifford, 283-307. New York: Feminist Press.

Anderson, Margaret L., and Patricia Hill Collins, eds. 2006. Race, class, and gender: An anthology. New York: Wadsworth.

Aptheker, Bettina. 1982. Woman's legacy: Essays on race, sex, and class in American bistory. Amherst: University of Massachusetts Press.

Avery, Vida. 2003. A fateful hour in black higher education: The creation of the Atlanta university system. PhD diss., Georgia State University.

Baham, Eva. 1997. Anna Julia Haywood Cooper, a stream cannot rise higher than its source: The vanguard as the panacea for the plight of black America. PhD diss., Purdue University.

Barry, Keith. 2005. Charles S. Johnson, Fisk University, and the struggle for civil rights, 1945-1970. PhD diss., Florida State University.

Beamon, Harry. 1979. The rise and demise of physical education at Fisk University: A historical analysis. EdD diss., Peabody College for Teachers of Vanderbilt University.

Bell-Scott, Patricia. 1980. Schoolin' "respectable" ladies of color: Issues in the history of black women's higher education. Journal of NAWDAC 43 (2): 22-28.

— 1997. To keep my self-respect: Dean Lucy Diggs Slowe's 1927 memorandum on the sexual harassment of black women. National Women's Studies Association Journal 9:70-77.

- n.d. The business of being dean of women: A letter from Lucy Diggs Slowe to Howard University board of trustees. Initiatives: The Journal of the National Association of Women's Education.

Berry, Mary Francis. 1982. Twentieth-century black women in education. The Journal of Negro Education 51 (3): 288-300.

Bethel, Leonard. 1975. The role of Lincoln University (PA) in the education of African leadership, 1854-1970. EdD diss., Rutgers, the State University of New Jersey.

Blackwell, Barbara. 1979. The advocacies and ideological commitments of a black educator: Mary McLeod Bethune, 1875-1955. PhD diss., University of Connecticut. 
Boisnier, Alicia. 2003. Race and women's identity development: Distinguishing between feminism and womanism among black and white women. Sex Roles 49 (5-6): 211-8.

Bond, Horace Mann. 1948. The evolution and present status of Negro higher and professional education in the United States. The Journal of Negro Education (Summer): 224-35.

. 1960. The origin and development of the Negro church-related college. The Journal of Negro Education 29 (3): 217-26.

. 1966. The education of the Negro in the American social order. New York: Octagon Books.

Bond, Jean Carey, and Patricia Perry. 1970. Is the black male castrated? In The black woman, edited by Toni Cade Bambara, 114-5. New York: Signet.

Bonner, Florence. 2001. Addressing gender issues in the historically black college and university community: A challenge and call to action. The Journal of Negro Education 70 (3): 176-91.

Bowles, Frank, and Frank A. DeCosta, eds. 1971. Between two worlds: A profile of Negro higher education. New York: McGraw-Hill.

Bracey, John. 2002. Afro-American women: A brief guide to writings from historical and feminist perspectives. Journal of Women's History 14 (Summer): 140-3.

Brazzell, Johnetta Cross. 1992. Bricks without straw: Missionary-sponsored black higher education in the post-emancipation era. The Journal of Higher Education 63 (1): 26-49.

Brown, Linda Beatrice. 1998. The long walk: The story of the presidency of Willa B. Player at Bennett College. Greensboro, NC: Bennett College Leadership Institute.

Brown, M. Christopher, James L. Davis, and Shendrick A. McClendon. 1999. Mentoring graduate students of color: Myths, models, and modes. Peabody Journal of Education, 74 (2): 105-18.

Brown, M. Christopher, and Kassie Freeman. 2004. Black colleges: New perspectives on policy and practice. Westport, CT: Praeger.

Browning, Jane E. Smith, and John B. Williams. 1978. History and goals of black institutions of higher learning. In Black colleges in America: Challenge, development, and survival, edited by Charles V. Willie and Ronald R. Edmonds, 68-96. New York: Teachers College Press.

Bullock, Henry Allen. 1967. A history of Negro education in the South from 1619 to the present. Cambridge, MA: Harvard University Press.

Burke, Beverly, Andrea Cropper, and Philomena Harrison. 2000. Real or imagined: Black women's experience in the academy. Community, Work, and Family 3 (December): 297-310.

Butchart, Ronald E. 1980. Northern schools, Southern blacks, and Reconstruction: Freedmen's education, 1862-1875. Westport, CT: Greenwood.

- 1998, "Outthinking and outflanking the owners of the world": A historiography of the African American struggle for education. History of Education Quarterly 28 (3): 333-66, 361.

Cade, Toni. 2005. The black woman. New York: Pocket Books.

Campbell, Clarice. 1970. A history of Tougaloo College. PhD diss., University of Mississippi.

Carroll, Constance. Three's a crowd: The dilemma of the black woman in higher education. In But some of us are brave: Blackwomen's studies, edited by Gloria Hull, Patricia Bell-Scott, and Barbara Smith, 115-28. New York: Feminist Press.

Cash, Gail. 1994. Women at Hampton, 1930-1959. PhD diss., Marquette University. Chancer, Lynn, and Beverly Watkins. 2006. Gender, race, and class. New York: Blackwell. 


\section{Gasman}

Chapel, Cynthia. 1997. Shifting history, shifting mission, shifting identity: The search for survival at Lincoln University (Jefferson City, Missouri), 1866-1997. EdD diss., Oklahoma State University.

Chivers, Walter. 1943. The founding of Spelman College: A challenge to Negro women. Spelman Messenger 59 (May): 7-10.

Clary, George. 1965. The founding of Paine College: A unique venture in inter-racial cooperation in the New South, 1882-1903. EdD diss., University of Georgia.

Cole, Johnnetta Betsch, and Beverly Guy-Sheftal. 2003. Gender talk: The struggle for women's equality in African American communities. New York: Random House.

Coleman-Burns, Patricia. 1989. African American Women: Education for What? Sex Roles 21 (1-2):145-60.

Collier-Thomas, Bettye. 1982. The impact of black women in education: An historical overview. Journal of Negro Education 51 (Summer): 254-65.

Collier-Thomas, Bettye, and V. P. Franklin, eds. 2001. Sisters in the struggle: African American women in the civil rights and Black Power movements. New York: New York University Press.

Collins, Alicia C. 2001. Black women in the academy: An historical overview. In Sisters of the academy: Emergent black women scholars in higher education, edited by Reitumetse Obakeng Mabokela and Anna L. Green, 28-41. Sterling, VA: Stylus.

- 2001. Socialization at two black women's colleges: Bennett College and Spelman College. EdD diss., University of Pittsburgh.

Collins, Patricia Hill. 1998. Fighting words: Black women and the search for justice Minneapolis: University of Minnesota Press.

- 1999. Black feminist thought: Knowledge, consciousness, and the politics of empowerment. New York: Taylor \& Francis.

- 2005. Black sexual politics: African Americans, gender, and the new racism. New York: Taylor \& Francis.

- 2006. From black power to hip hop: Racism, nationalism, and feminism. Philadelphia, PA: Temple University Press.

Comminey, Shawn. 2003. A history of straight college, 1869-1935. PhD diss., Florida State University.

Crawford, Vicki, Jacqueline Rouse, and Barbara Woods, eds. 1993. Women in the civil rights movement: Trailblazers and torchbearers, 1941-1965. Bloomington: Indiana University Press.

Cuthbert, Marian. 1987. Education and marginality: A study of the Negro woman college graduate. New York: Garland.

Dagbovie, Pero Gaglo. 2003. Black women, Carter G. Woodson, and the Association for the Study of Negro Life and History, 1915-1950. The Journal of African American History, 88 (1): 21-41.

- 2004. Black women historians from the late 19th century to the dawning of the civil rights movement. The Journal of African American History 89 (3): 241-61.

Davidson, Martin N., and Lynn Foster-Johnson. 2001. Mentoring in the preparation of graduate researchers of color. Review of Educational Research 71 (4): 549-74.

Davis, Angela Y. 1983. Women, race, and class. New York: Vintage.

Davis, Lenwood. 1979. A history of Livingstone College, 1879-1957. PhD diss., Carnegie Mellon University.

Davis, Leroy. 1989. John Hope of Atlanta: Race leader and black educator. PhD diss., Kent State University.

Dill, Bonnie Thorton, and Bruce B. Williams. 1992. Race, gender, and poverty in the rural South: African American single mothers. In Rural poverty in America, edited by Cynthia Duncan, 97-110. New York: Auburn House. 
Drewry, Henry, and Humphrey Doermann. 2001. Stand and prosper: Private black colleges and their students. Princeton, NJ: Princeton University Press.

DuBois, W. E. B. 1902. Of the training of black men. Atlantic Monthly 90:289-97.

Dyson, Walter. 1941. Howard University: The capstone of Negro education. A history, 1897-1940. Washington, DC: The Graduate School at Howard University.

Eagleston, Oran, and Eleanor Bell. 1945. The values of Negro women college students. Journal of Social Psychology 22 (November): 149-54.

Edwards, Ishmell. 1993. History of Rust College, 1866-1967. PhD diss., University of Mississippi.

Eisenmann, Linda. 2001. Creating a framework for interpreting U.S. women's educational history: Lessons from historical lexicography. History of Education 30 (5): 453-70.

Engs, Robert. 1999. Educating the disenfranchised and disinherited: Samuel Chapman Armstrong and the Hampton Institute, 1839-1893. Knoxville: University of Tennessee.

Evans, Stephanie Y. 2003. Living legacies: Black women, educational philosophies, and community service, 1865-1965. PhD diss., University of Massachusetts, Amherst.

- 2007. Black women in the ivory tower, 1850-1954. Gainesville: University Press of Florida).

Evans-Herring, Cassandra. 2003. An intersectional analysis of the life experiences of Mary Elizabeth Branch, the first female senior college president. PhD diss., Georgia State University.

Fairclough, Adam. 2000. "Being in the field of education and also being a Negro ... seems . . . tragic": Black teachers in the Jim Crow South. The Journal of American History, 87 (1): 65-91, 80.

Fancher, Evelyn. 1975. Tennessee State University (1912-1974): A history of an institution with applications for the future. PhD diss., Peabody College for Teachers of Vanderbilt University.

Favors, Jelani. 2006. Shelter in a time of storm: Black colleges and the rise of student activism in Jackson, Mississippi. PhD diss., Ohio State University.

Foster, Terry. 1992. A historical examination of the changing mission of Kentucky State University. EdD diss., Indiana University.

Fox-Genovese, Elizabeth. 1988. Within the plantation household: Black and white women of the Old South. Chapel Hill: University of North Carolina Press.

Francis, Valera T. 2004. Pride and paradox: The history and development of Southern University at New Orleans, 1954-1975. PhD diss., University of New Orleans.

Franklin, V. P. 2002. Hidden in plain view: African American women, radical feminism, and the origins of women's studies programs, 1967-1974. The Journal of African American History 87 (Autumn): 433-45.

Frazier, E. Franklin. 1951. Negro family in the United States. New York: Dryden.

Freeman, Kassie. 1998. African American culture and heritage in higher education research and practice. Westport, CT: Praeger.

Fultz, Michael. 1995. Teacher training and African American education in the South, 1900-1940. The Journal of Negro Education, 64 (2): 196-210.

Gallot, Mildred. 1982. Grambling State University: A history, 1901-1977. EdD diss., Louisiana State University and Agricultural and Mechanical College.

Garrett, R. Thomas. 1989. A study of the transition of Bluefield State College from a black teacher preparation college to a predominantly white liberal arts college. EdD diss., Rutgers, the State University of New Jersey.

Gasman, Marybeth. 2000. A renaissance in Nashville: Charles S. Johnson's use of philanthropy to build Fisk University in the post-war period. PhD diss., Indiana University. 


\section{Gasman}

2006. Salvaging "academic disaster areas": The black college response to Christopher Jencks' and David Riesman's 1967 Harvard Educational Review article. Journal of Higher Education 77 (2): 317-52.

2007. Envisioning black colleges: A history of the United Negro College Fund. Baltimore, MD: Johns Hopkins University Press.

Gasman, Marybeth, Benjamin Baez, and Caroline Sotello Turner. Forthcoming. Understanding minority serving institutions. New York: State University of New York Press.

Gasman, Marybeth, Cynthia Gerstl-Pepin, Sibby Anderson-Thompkins, Lisa Rasheed, and Karry Hathaway. 2004. Developing trust, negotiating power: Transgressing race and status in the academy. Teachers College Record 106 (4): 689-715.

Gasman, Marybeth, and Katherine V. Sedgwick, eds. 2005. Uplifting a people: African American philanthropy and education. New York: Peter Lang.

Gibson, De Lois. 1972. A historical study of Philander Smith College, 1877-1969. EdD diss., University of Arkansas.

Giddings, Paula. 1984. When and where I enter: The impact of black women on race and sex in America. New York: Quill William Morrow.

-1994. In search of sisterhood: Delta Sigma Theta and the challenge of the black sorority movement. New York: Amistad Books.

Gilkes, Cheryl Townsend. 2000. If it wasn't for the women . . .: Black women's experience and womanist culture in church and community. New York: Orbis Books.

Gilpin, Patrick J., and Marybeth Gasman. 2003. Charles Spurgeon Johnson: Leadership behind the veil in the age of Jim Crow. Albany: State University of New York Press.

Glenn, Evelyn Nakano. 1998. The social construction and institutionalization of gender and race: An integrative framework. In The gender lens: Revisioning gender, edited by Myra M. Ferree, Judith Lorber, and Beth Hess, 3-15. Thousand Oaks, CA: Sage.

Graham, Frances D. 1996. The founding of an all black female seminary: Spelman, 1881-1927. PhD diss., University of Illinois at Urbana-Champaign.

Graham, Frances D., and Susan L. Poulson. 2006. Spelman College: A place all their own. In Challenged by coeducation: Women's colleges since the 1960s, edited by Leslie Miller-Bernal and Susan L. Poulson, 234-56. Nashville: Vanderbilt University Press.

Gurin, Patricia, and Edgar Epps. 1975. Black consciousness, identity, and achievement: A study of students in historically black colleges. New York: John Wiley.

Guy-Sheftal, Beverly. 1995. Words of fire: An anthology of African American feminist thought. New York: New Press.

Guy-Sheftal, Beverly, and Jo Moore Stewart, eds. 1981. Spelman: A centennial celebration. Atlanta, GA: Spelman College.

Hansen, Joyce A. 1997. The ties that bind: Mary McLeod Bethune and the political mobilization of African-American women. PhD diss., University of Connecticut.

- 2003. Mary Mcleod Bethune and black women's political activism. Columbia: University of Missouri Press.

Harley, Sharon. 2002. Sister circle: Black women and work. Piscataway, NJ: Rutgers University Press.

Harper, Shaun R. 2005. High-achieving African American men's behavioral responses to stereotypes at predominantly white universities. Paper presented at the annual meeting of the Association for the Study of Higher Education, Philadelphia, PA, November 17-19. 
Henry, L. 1981. Promoting historical consciousness: The early archives, Committee of the National Council of Negro Women. Signs: Journal of Women in Culture and Society 7 (1): 251-9.

Higginbotham, Elizabeth. 2001. Too much to ask: Black women in the era of integration. Chapel Hill: University of North Carolina Press.

Hill, S. T., and M. M. Green. 2007. Science and engineering degrees, by race/ethnicity of recipients: 1995-2004. Arlington, VA: National Science Foundation.

Hine, Darlene Clark. 1990. Black women in United States history: From colonial times to the present. Brooklyn, NY: Carlson.

- 1994. Black women and the re-construction of American history. Bloomington: Indiana University Press.

- 1998. A shining thread of hope: The bistory of black women in America. New York: Broadway Books.

—, ed. 2005. Black women in America. New York: Oxford University Press.

Hine, Darlene Clark, Elsa Barkley Brown, and Rosalyn Terborg-Penn, eds. 1994. Black women in America: An historical encyclopedia. Bloomington: Indiana University Press.

Hine, Darlene Clark, and Kathleen Thompson, eds. 1999. A shining thread of hope: A bistory of black women in America. New York: Broadway Books.

Holmes, Dwight O. W. 1934. The beginnings of the Negro college. The Journal of Negro Education, 3 (2): 168-93.

- 1949. Seventy years of the Negro college, 1860 to 1930. Phylon 10 (4): $307-13$.

-1969. Evolution of the Negro college. New York: Ayer Company.

hooks, bell. 1981. "Ain't I a woman": Black women and feminism. Boston: South End.

- 1990. Yearning: Race, gender, and cultural politics. New York: South End.

- 2000. Feminist theory: From margin to center. Boston: South End.

Hunter, Wilma. 1982. Coming of age: Hollis B. Frissell and the emergence of Hampton Institute, 1893-1917. PhD diss., Indiana University.

Hutcheson, Philo A. Forthcoming. Shall I compare thee? Reflections on naming and power. In Understanding Minority Serving Institutions, edited by Marybeth Gasman, Benjamin Baez, and Caroline Sotello Turner. New York: State University of New York Press.

Ihle, Elizabeth. L. 1992. Black women in higher education: An anthology of essays, studies, and documents. New York: Garland.

Irving, John. 1949. Negro students and their colleges. Boston: Meador.

Isaacs, Barbara. 2002. The lunch counter struggle, 1960-1963: Women Re-mapping boundaries of race, gender, and vocation. PhD diss., Northwestern University.

Jabs, Albert. 1983. The mission of Voorhees College: Its roots and its future. EdD diss., University of South Carolina.

Jackson, Gretchen. 2005. A historical analysis of the development of Southern University and its teacher education program. EdD diss., University of Houston.

Jaffe, Abram J., Walter Adams, and Sandra G. Meyers. 1968. Negro higher education in the 1960's. Westport, CT: Praeger.

James, Joy, and T. D. Sharpley-Whiting, eds. 2000. The black feminist reader. New York: Blackwell.

Jencks, Christopher, and David Riesman. 1967. The American Negro college. Harvard Educational Review 37 (2): 3-60.

Jenkins, Clara. 1965. An historical study of Shaw University, 1865-1963. EdD diss., University of Pittsburgh.

Johnson, Alandus. 1970. The growth of Paine College: A successful interracial venture. PhD diss., University of Georgia. 


\section{Gasman}

Johnson, Karen Ann. 1997. Uplifting the women and the race: A black feminist theoretical critique of the lives, works and the educational philosophies of Anna Julia Cooper and Nannie Helen Burroughs. PhD diss., University of California, Los Angeles.

Jones, Charisse, and Kumea Shorter-Gooden. 2003. Shifting: The double lives of black women in America. New York: HarperCollins.

Kates, Susan. 2001. Elocution and African American culture: The pedagogy of Hallie Quinn Brown. In Activist rhetorics and American higher education, edited by Susan Kates, 53-74. Carbondale and Edwardsville: Southern Illinois University Press.

Katz, Michael B, Mark J. Stern, and Jamie J. Fader. 2005. Women and the paradox of economic inequality in the twentieth-century. Journal of Social History 39 (1): 65-88.

Keller, F. R. 1999. An educational controversy: Anna Julia Cooper's vision of resolution. National Women's Studies Association Journal 11 (3): 49-67.

Kittrell, Flemmie. Home economics at Bennett College for Women. 1931. Southern Workman 60:381-4.

Klein, Arthur L. 1969. Survey of Negro colleges and universities. New York: Negro Universities Press.

Kobena, Korang-Arthur. 1992. The history of Paul Quinn College: Austin and Waco years. PhD diss., University of North Texas.

Lefhever, Harry G. 2005. Undaunted by the fight: Spelman College and the civil rights movement, 1957-1967. Macon, GA: Mercer University Press.

Lemert, C., and E. Bhan, eds. 1998. The voice of Anna Julia Cooper: Including A voice from the South and other important essays, papers, and letters. Lanham, MD: Rowman \& Littlefield.

Leone, Janice. 1989. The mission of women's colleges in an era of cultural revolution, 1890-1930. PhD diss., Ohio State University.

Liberti, Rita. 1999. "We were ladies, we just played like boys": African American womanhood and competitive basketball at Bennett College, 1928-1942. Journal of Sport History (26) 3: 567-84.

. 2000. Exploring the place and significance of physical education at black colleges and universities during the late nineteenth and early twentieth centuries. Western College Physical Education Society Monograph Series. Pullman: Washington State University.

2004. Fostering community consciousness: The role of women's basketball at black colleges and university, 1900-1950. In Race and sport: The struggle for equality on and off the field, edited by Charles K. Ross, 40-58. Oxford: University of Mississippi Press.

Linsin, C. 1997. Something more than a creed: Mary McLeod Bethune's aim of integrated autonomy as director of Negro affairs. Florida Historical Quarterly 76 (1): $20-41$.

Lockwood, Nadine. 2004. Bennett College for Women, 1926-1966. PhD diss., State University of New York at Buffalo.

Logan, Rayford. 1958. The evolution of private colleges for Negroes. The Journal of Negro Education, 27 (3): 213-20.

- 1979. Howard University: The first hundred years, 1867-1977. New York: New York University Press.

Matthews, Lamoyne. 1976. Portrait of a dean: A biography of Inabel Burns Lindsay, first dean of the Howard School of Social Work. PhD diss., University of Maryland.

McCluskey, Audrey T. 1991. Mary McLeod Bethune and the education of black girls in the South, 1904-1923. PhD diss., Indiana University. 
1994. Multiple consciousness in the leadership of Mary McLeod Bethune. National Women's Studies Association Journal 6 (1): 69-81.

- 1994. Ringing up a school: Mary McLeod Bethune's impact on Daytona. Florida Historical Quarterly 73 (2): 200-17.

- 1997. We specialize in the wholly impossible: Black women school founders and their mission. Signs: Journal of Women in Culture and Society 22 (2): 403-26.

- 1999. Representing the race: Mary McLeod Bethune and the press in the Jim Crow era. Western Journal of Black Studies 23 (4): 236-45.

McCluskey, Audrey T., and Elaine M. Smith, eds. 2002. Mary McLeod Bethune. Bloomington: Indiana University Press.

McGinnis, Frederick. 1940. A history of Wilberforce University. PhD diss., University of Cincinnati.

McGrath, Earl J. 1965. The predominantly Negro colleges and universities in transition. New York: Teachers College, Columbia University.

McJamerson, Jimmy. 2005. Grambling State University: The spirit, the history, and the legacy through the experience of pioneers and builders. PhD diss., Union Institute and University.

McKinny, Richard I. 1998. Mordecai, the man and his message: The story of Mordecai Wyatt Johnson. Washington, DC: Howard University Press.

McKinney, Theophilus. 1932. Higher education among Negroes. Charlotte, NC: Johnson C. Smith University Press.

McMillian, Joseph. 1986. The development of higher education for blacks during the late nineteenth century: A study of the African American Methodist Episcopal Church, Wilberforce University, the American Missionary Association, Hampton Institute, and Fisk University. EdD diss., Columbia University, Teachers College.

Miller, Kelly. 1933. The past, present and future of the Negro college. The Journal of Negro Education 2 (3): 411-22.

Morton, Patricia. 1991. Disfigured images: The historical assault on Afro-American women. Westport, CT: Greenwood.

Moses, Yolanda. 1989. Black women in academe: Issues and strategies. Washington, DC: Association of American Colleges and Universities.

Moynihan, Daniel Patrick. 1965. The Negro family: The case for national action. Washington, DC: Department of Labor.

Muse, Clifford. 1989. An educational stepchild: Howard University during the New Deal, 1933-1945. PhD diss., Howard University.

Myers, Lena Wright. 2002. A broken silence: Voices of African American women in the academy. Westport, CT: Bergin \& Garvey.

National Association of College Women. 1937. Memorial tributes to Lucy Slowe. National Association of College Women Journal 14:49-51.

Nidiffer, Jana . 1999. Pioneering deans: More than wise and pious matrons. New York: Teachers College Press.

- 1999. Poor historiography: Challenges and dilemmas in exploring the history of the "Poorest" in American higher education. History of Education Quarterly 39 (3): 321-36.

Noble, Jeanne L. 1956. The Negro woman's college education. New York: Columbia University Press.

- 1957. Negro women today and their education. The Journal of Negro Education 26 (1): 15-21.

O'Brien, G. 1976. Five campuses hit by protest. The Chronicle of Higher Education, May 3, p 4.

Palmieri, Patricia. 1997. From republican motherhood. In The history of higher education, edited by Lester Goodchild, 173-82. New York: Simon \& Schuster. 


\section{Gasman}

Parker, Marjorie. 1999. Past is prologue: The history of Alpha Kappa Alpha, 1908-1999 (Washington, DC: Alpha Kappa Alpha.

Parsons, M. 1908. Mount Holyoke of the South. Home Mission Monthly.

Peeps, Stephen J. 1981. Northern Philanthropy and the emergence of black higher education: Do gooders, compromisers, or co-conspirators? The Journal of Negro Education 50 (3): 251-69.

Perkins, Linda M. 1982. "Head life's demands": The educational philosophy of Fanny Jackson Coppin. The Journal of Negro Education 51 (3): 181-90.

- 1987. Fanny Jackson Coppin and the Institute for Colored Youth, 1865-1902. New York: Garland.

- 1988. The racial integration of the Seven Sisters. The Journal of Blacks in Higher Education 19 (Spring): 104-8.

- 1996. Lucy Diggs Slowe: Champion of the self-determination of African American women in higher education. The Journal of Negro History, 81 (1-4): 89-104.

- 1997. Cult of true womanhood. In The history of higher education, edited by Lester Goodchild, 183-90. New York: Simon \& Schuster.

- 1997. For the good of the race: Married African-American academics-A historical perspective. In Academic couples: Problems and promises, edited by Marianne A. Ferber and Jane W. Loeb, 80-105. Urbana and Chicago: University of Illinois Press.

Player, Willa. 1960. Report to the executive committee of the board of trustees. Bennett College Archives, Greensboro, North Carolina, 21

Poole, H. Randall. 1989. From black to white: The transition of Bluefield State College from an historically black college to a predominantly white institution. PhD diss., University of Maryland.

Ramsey, Berkley. 1973. The public black college in Georgia: A history of Albany State College, 1903-1965. PhD diss., Florida State University.

Read, Florence. 1937. The place of women's college in the pattern of Negro education. Opportunity 15:267-70.

- 1961. The story of Spelman College. Princeton, NJ: Princeton University Press.

Richardson, Frederick. 1973. A power for good in society: The history of Benedict College. PhD diss., Florida State University.

Roane, Florence. 1965. A cultural history of professional teacher preparation at Bethune-Cookman College. EdD diss., Boston University.

Robinson, William. 1954. The history of Hampton Institute, 1868-1949. PhD diss., New York University.

Romelle, Charlestine. 1990. A history of Claflin College, 1869-1987. PhD diss., University of South Carolina.

Rosenblum, Karen, and Toni-Michelle C. Travis. 2005. Meaning of difference: American constructions of race, sex and gender, social class, and sexual orientation. New York: Blackwell.

Ross, B. J. 1975. Mary McLeod Bethune and the National Youth Administration: A case study of power relationships in the Black Cabinet of Franklin D. Roosevelt. The Journal of Negro History 60 (1): 1-28.

Rothman, Norman. 1981. Curriculum formation in a black college: A study of Morris Brown College, 1881-1980. PhD diss., Georgia State University.

Rovaris, Dereck. 1990. Developer of an institution: Dr. Benjamin E. Mays, Morehouse College President, 1940-1967. PhD diss., University of Illinois at UrbanaChampaign.

Sanders, Katrina. 1997. Building racial tolerance through education: The Fisk University Race Relations Institute, 1944-1969. PhD diss., University of Illinois at Urbana-Champaign. 
Seymour, Elaine, and Nancy Hewitt. 2000. Talking about leaving: Why undergraduates leave the sciences. Boulder, CO: Westview.

Shaw, Stephanie. 1996. What a woman ought to be and do: Black professional women and workers during the Jim Crow era. Chicago: University of Chicago Press.

Slowe, Lucy Diggs. 1933. Higher education of Negro women. The Journal of Negro Education, 2 (3): 352-8.

- 1937. A colored girl enters college: What shall she expect? Opportunity (September): 276.

Smith, Elaine. 1996. Mary McLeod Bethune's "last will and testament": A legacy for race vindication. The Journal of Negro History 81 (1-4): 105-22.

Smith, Valerie. 1998. Not just race, not just gender: Black feminist readings. New York: Routledge.

Solomon, Barbara. 1985. In the company of educated women. New Haven, CT: Yale University Press.

Spencer, Chonita Robinson. 1988. A study of the contributions of Stephen J. Wright, an American education. EdD diss., Rutgers, the State University of New Jersey.

Sterling, Dorothy. 1997. We are your sisters: Black women in the nineteenth century (New York: Norton).

Stringer, Patricia S., and Irene Thompson. 1982. Stepping off the pedestal: Academic women in the South. New York: Modern Language Association of America.

Sutton, Virginia Ann. 1969. The early history of Bennett College. Self-published, Winston-Salem, NC.

Taliaferro, Cecil. 1975. Virginia Union University, the first one hundred years, 1865-1965. PhD diss., University of Pittsburgh.

Thompson, Daniel C. 1973. Private black colleges at the crossroads. Westport, CT: Greenwood.

Thompson, Kathleen, and Hilary Mac Austin, eds. 2000. The face of our past: Images of black women from colonial America to the present. Bloomington: Indiana University Press.

Thurgood Marshall Fund and Shirley M. Geiger. 2007. Understanding gender at public historically black colleges and universities. Washington, DC: Thurgood Marshall Fund.

Thurman, Frances. 1978. The history of Saint Paul's College, Lawrenceville, Virginia, 1888-1959. PhD diss., Howard University.

The traditionally black institutions of higher education, 1860-1982. 1983. Washington, DC: National Center for Educational Statistics.

Tucker, Aviezar. 2004. Our knowledge of the past: A philosophy of historiography. New York: Cambridge University Press.

Vanlandingham, Karen. 1985. In pursuit of a changing dream: Spelman College students and the civil rights movement, 1955-1962. Master's thesis, Emory University.

Venkatesan, Madhavi. 1996. Black higher education and the American labor market: A century at Fisk University. PhD diss., Vanderbilt University.

Wadelington, Charles Weldon, and Richard Knapp. 1999. Charlotte Hawkins Brown and Palmer Memorial Institute: What one young African American woman could do. Chapel Hill: University of North Carolina Press.

Wallace, Michelle. 1999. Black macho and the myth of the superwoman. New York: New Left Books.

Warren-Christian, Christiane. 2003. Anna Julia Cooper: Feminist and scholar. PhD diss., Drew University.

Washington, Elsie. 1993. Uncivil war: The struggle between black men and women. New York: Noble Press. 


\section{Gasman}

Washington, Valora, and Joanna Newman. 1991. Setting our own agenda: Exploring the meaning of gender disparities among blacks in higher education. The Journal of Negro Education 60 (1): 19-35.

Watkins, William. 2001. White architects of black education: Ideology and power in America, 1865-1954. New York: Teachers College Press.

Watson, Yolanda, and Sheila T. Gregory. 2005. Daring to educate: The legacy of early Spelman College presidents. Sterling, Virginia: Stylus.

Watson-Moore, Yolanda. 2000. Training the head, the hand, and the heart: The evolution of the academic curriculum of Spelman College, 1881-1953. PhD diss., Georgia State University.

Weiler, Kathleen. 2006. The history of gender and progressive education in the United States. Paedagogica Historica 42 (1-2): 161-76.

White, Deborah Gray. 1999. Too heavy a load: Black women in defense of themselves, 1894-1994. New York: Norton.

Williams, Juan, and Dwayne Ashley. 2004. "I'll find a way or make one": A tribute to bistorically black colleges and universities. New York: Amistad Books.

Williams, Zachery. 2003. In search of the talented tenth: Howard University intellectuals and the dilemmas of race in academia, 1926-1970. PhD diss., Bowling Green State University.

Williamson, Joy A. 2004. "This has been quite a year for heads falling": Institutional autonomy in the civil rights era. History of Education Quarterly 44 (4): 489-511.

Willie, Charles V., and Ronald R. Edmonds, eds. 1978. Black colleges in America: Challenge, development, and survival. New York: Teachers College Press.

Willie, Charles V., Richard J. Reddick, and Roland Brown. 2006. The black college mystique. Lanham, MD: Rowman \& Littlefield.

Wimbish, Jerrold. 2000. Student activism and the historically black university: Hampton Institute and Howard University, 1960-1972. EdD diss., Harvard University.

Wolters, Raymond. 1975. The new Negro on campus: Black college rebellions of the 1920s. Princeton, NJ: Princeton University Press.

Woodson, Carter G. 1919. The education of the Negro prior to 1861: A bistory of the education of the colored people of the United States from the beginning of slavery to the Civil War. New York: Kessinger.

- 1933. The mis-education of the Negro. New York: Associated Publishers.

Woody, Thomas. 1929. A history of women's education in the United States. New York: Octagon Books.

Wright, Earl. 2000. Atlanta University and American sociology, 1896-1917: An earnest desire for the truth despite its possible unpleasantness. PhD diss., University of Nebraska, Lincoln.

Yellin, Jean Fagan. 1973. Du Bois crisis and woman's suffrage. The Massachusetts Review 14 (Spring): 365-75.

Young, Jacqueline. 1987. A study of the education philosophies of three pioneer black women and their contributions to American education (Coppin, Bethune, and Brown). EdD diss., Rutgers, the State University of New Jersey.

Manuscript received October 17, 2006

Revision received April 4, 2007

Accepted June 5, 2007 